\title{
Estradiol Upregulates Progesterone Receptor and Orphanin FQ Colocalization in Arcuate Nucleus Neurons and Opioid Receptor-Like Receptor-1 Expression in Proopiomelanocortin Neurons That Project to the Medial Preoptic Nucleus in the Female Rat
}

\author{
Nayna M. Sanathara Justine Moreas Matthew Mahavongtrakul Kevin Sinchak \\ Department of Biological Sciences, California State University, Long Beach, Long Beach, Calif., USA
}

\section{Key Words \\ Proopiomelanocortin · ORL-1 - Nociceptin · Fluoro-Gold . Lordosis - Female reproductive behavior - Medial preoptic nucleus $\cdot \mu$-Opioid receptors · Orphanin FQ}

\begin{abstract}
Background: Ovarian steroids regulate sexual receptivity in the female rat by acting on neurons that converge on proopiomelanocortin (POMC) neurons in the arcuate nucleus of the hypothalamus (ARH) that project to the medial preoptic nucleus (MPN). Estradiol rapidly activates these neurons to release $\beta$-endorphin that activates MPN $\mu$-opioid receptors (MOP) to inhibit lordosis. Lordosis is facilitated by the subsequent action of progesterone that deactivates the estradiolinduced MPN MOP activation. Orphanin FQ $(\mathrm{OFQ} / \mathrm{N}$; also known as nociceptin) infusions into the $A R H$, like progesterone, deactivate MPN MOP and facilitate lordosis in estradiolprimed rats. OFQ/ $\mathrm{N}$ reduces the activity of $\mathrm{ARH} \beta$-endorphin neurons through post- and presynaptic mechanisms via its cognate receptor, ORL-1. Methods: We tested the hypotheses that progesterone receptors (PR) are expressed in ARH $\mathrm{OFQ} / \mathrm{N}$ neurons by immunohistochemistry and ORL-1 is expressed in POMC neurons that project to the MPN by com-
\end{abstract}

bining Fluoro-Gold injection into the MPN and double-label fluorescent in situ hybridization (FISH). We also hypothesized that estradiol increases coexpression of PR-OFQ/N and ORL-1-POMC in ARH neurons of ovariectomized rats. $\boldsymbol{R e}$ sults: The number of $\mathrm{PR}$ - and $\mathrm{OFQ} / \mathrm{N}$-immunopositive $\mathrm{ARH}$ neurons was increased as was their colocalization by estradiol treatment. FISH for ORL-1 and POMC mRNA revealed a subpopulation of ARH neurons that was triple labeled, indicating these neurons project to the MPN and coexpress ORL1 and POMC mRNA. Estradiol was shown to upregulate ORL1 and POMC expression in MPN-projecting ARH neurons. Conclusion: Estradiol upregulates the ARH OFQ/N-ORL-1 system projecting to the MPN that regulates lordosis.

(c) 2014 S. Karger AG, Basel

\section{Introduction}

Proopiomelanocortin (POMC) neurons are located in the arcuate nucleus of the hypothalamus $(\mathrm{ARH})$ and regulate reproduction and energy balance [1]. The activity of subsets of ARH POMC, putative $\beta$-endorphin ( $\beta$-END), neurons is regulated by ovarian steroids that signal through multisynaptic neurocircuits that converge on

\section{KARGER}

E-Mail karger@karger.com

www.karger.com/nen
(C) 2014 S. Karger AG, Basel

0028-3835/14/1003-0103\$39.50/0 


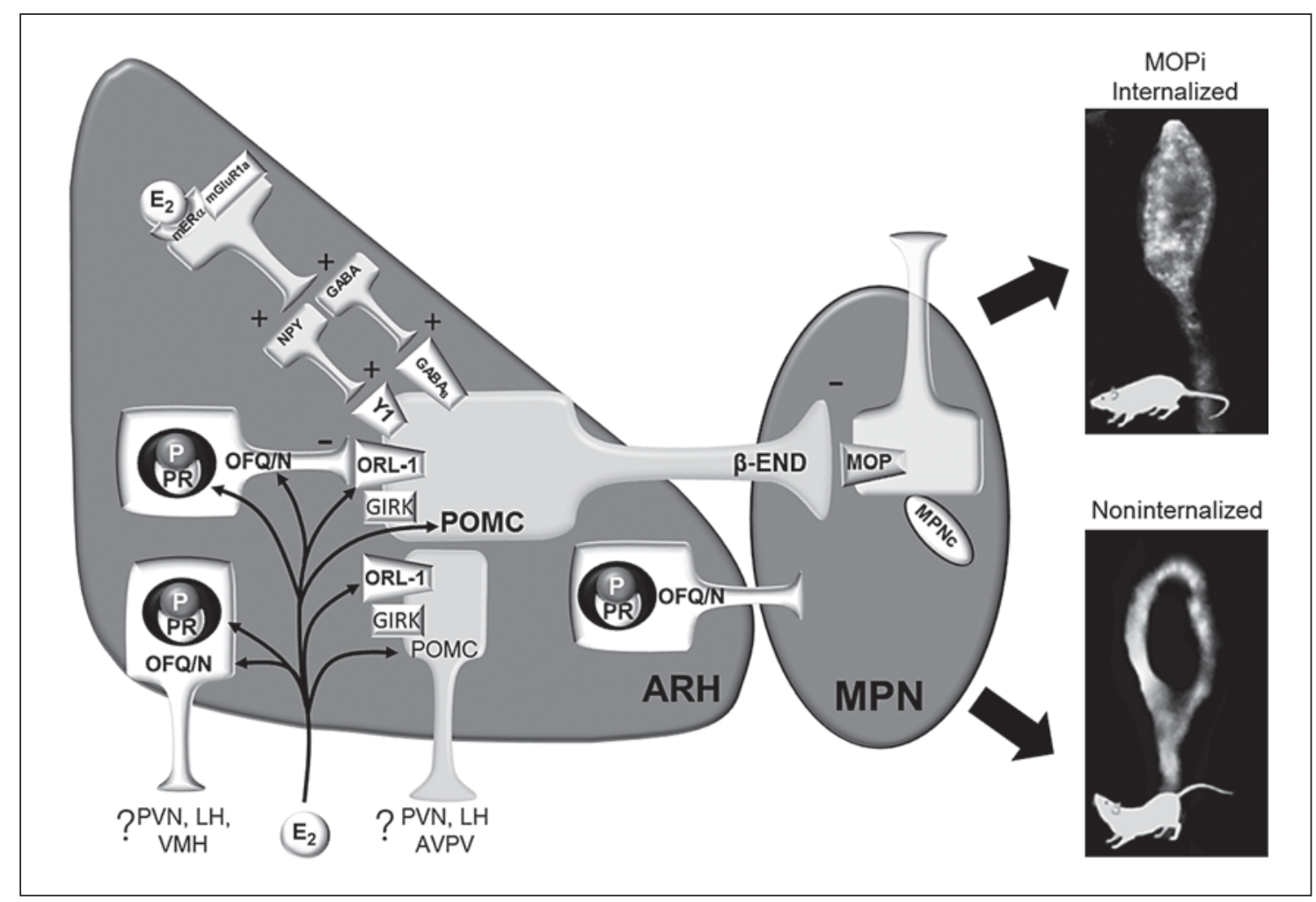

Fig. 1. ARH-MPN model lordosis circuit. Estradiol $\left(\mathrm{E}_{2}\right)$ binds to a membrane $\mathrm{ER} \alpha(\mathrm{mER} \alpha)$ that complexes with and signals through mGluR1a to directly or indirectly (illustrated) induce the release of NPY and GABA that binds to the NPY-Y1 receptor (Y1) and $\mathrm{GABA}_{\mathrm{B}}$ receptors, respectively, on a subpopulation of POMC neurons that project to the MPN $[4,7,32]$. This rapidly induces and maintains $\beta$-END release in the MPN that activates and internalizes MOP into early endosomes and is measured by levels of MOP immunoreactive (MOPi) staining (MOPi internalized photomicrograph) $[3,5]$. This MOP activation is associated with actively inhibiting lordosis. $\mathrm{E}_{2}$ increases the number of $\mathrm{ARH}$ neurons that coexpress $\mathrm{PR}$ and $\mathrm{OFQ} / \mathrm{N}$ (experiment I), and increases POMC and ORL-1 expression in ARH neurons that project to the MPN (experiments II and III). Steroid priming that facilitates lordosis,

POMC neurons to regulate the onset and termination of sexual receptivity in the female rat [2-5]. Estradiol initially inhibits sexual receptivity by activating a population of POMC neurons that project to the medial preoptic nucleus (MPN; fig. 1). These POMC neurons release $\beta$-END that activates and internalizes MPN $\mu$-opioid receptors (MOP) to inhibit sexual receptivity $[3,4,6]$. Estradiol activates a membrane-associated estrogen receptor- $\alpha(\mathrm{ER} \alpha)$ that complexes with and signals through the metabotropic glutamate receptor type 1a (mGluR1a; fig. 1) [711]. This ERa-mGluR1a signaling rapidly induces $\gamma$-aminobutyric acid (GABA) and neuropeptide Y (NPY) we hypothesize, deactivates this circuit by inducing $\mathrm{OFQ} / \mathrm{N}$ release in a subpopulation of $\mathrm{OFQ} / \mathrm{N}$ neurons that synapse onto POMC neurons that project to the MPN to activate ORL-1 and decrease $\beta$-END release through increasing outward GIRK $\mathrm{K}^{+}$currents [29, 30]. This recycles MPN MOP back to the plasma membrane and reduces MPN MOP activation/internalization to facilitate lordosis (noninternalized MOPi photomicrograph) [2-5, 7, 8, 27-30]. Populations of estradiol-induced OFQ/N-PR neurons could also project to the MPN, VMH, paraventricular nucleus of the hypothalamus (PVN), and lateral hypothalamus (LH) to regulate sexual receptivity and energy balance. Further, subpopulations of ORL1-POMC neurons could project to the PVN, LH and AVPV to regulate energy balance and reproductive feedback loops.

neurotransmission to induce $\beta$-END release that activates/internalizes MPN MOP and inhibits sexual receptivity - lordosis (fig. 1) [4, 7-9].

Concurrent with activation of this lordosis inhibitory circuit, estradiol also primes neurocircuits for facilitation of lordosis [12-21]. For example, progesterone receptors (PR) necessary for facilitation of lordosis are upregulated, as are orphanin FQ (also known as nociceptin; OFQ/N) and opioid receptor-like receptor-1 (ORL-1, also known as NOP [22]) protein and mRNA expression, and the functional coupling of ORL-1 to its G protein in the mediobasal hypothalamus [12, 21, 23-26]. In the ARH-MPN 
lordosis model neurocircuit, OFQ/N and ORL-1 are important for the inhibition of $\beta$-END neurons that project to the MPN to facilitate lordosis (fig. 1). Following estradiol priming, intracerebroventricular and site-specific infusions of OFQ/N that activate ORL-1 in the ventromedial hypothalamus (VMH)-ARH regions deactivate MPN MOP and facilitate lordosis [5, 21, 23, 27].

The facilitation of lordosis by either subsequent progesterone or prolonged exposure to estradiol is associated with reduced MPN MOP activation, presumably through inhibition of $\beta$-END release after estradiol priming. POMC neuronal activity can be reduced through preand postsynaptic mechanisms that are mediated by the OFQ/N-ORL-1 opioid peptide system [28-30]. OFQ/N directly reduces POMC activity through activation of ORL-1 on POMC neurons which increases outward potassium currents through $G$ protein-gated inwardly rectifying potassium (GIRK) channels (fig. 1) [28-30]. $\mathrm{OFQ} / \mathrm{N}$ has also been shown to act presynaptically to decrease excitatory glutamatergic neurotransmission to POMC neurons while enhancing GABAergic inhibitory neurotransmission to POMC neurons [29, 30]. Further, these pre- and postsynaptic actions of the OFQ/N-ORL-1 system on POMC neuronal activity have been shown to be regulated by estradiol and progesterone in a manner that is congruent with the expression of sexual receptivity (fig. 1) [29, 30].

In experiment I, we tested the hypothesis that $\mathrm{PR}$ are expressed in $\mathrm{OFQ} / \mathrm{N}$ neurons and that estradiol upregulates their coexpression in the ARH using double-label immunohistochemistry. Further, in experiment II, we tested the hypotheses that ARH POMC neurons that project to the MPN express ORL-1 using double-label fluorescent in situ hybridization (FISH) and the retrograde tract tracer Fluoro-Gold (FG; Fluorochrome, LLC, Denver, Colo., USA), and that estradiol upregulates their coexpression. In experiment III, we used Western blot analysis to confirm the estradiol regulation of ARH ORL-1 protein expression.

\section{Material and Methods}

\section{Animals}

All animals were adult female Long-Evans ovariectomized (OVX) rats (200-225 g) that were purchased from Charles River Laboratory Inc. (Wilmington, Mass., USA). Ovariectomy was performed by the supplier. Animals were housed in a climate- and light-controlled room (12/12 L/D cycle, lights on at 06:00 h) with food and water available ad libitum. All procedures were approved by the California State University, Long Beach IACUC.

\section{Experiment I}

To test the hypothesis that $\mathrm{PR}$ are expressed in OFQ/N ARH neurons and that estradiol increases the expression and colocalization of OFQ/N and PR, immunohistochemistry was performed in the region of the ARH on $17 \beta$ - estradiol benzoate (EB) - or oiltreated, colchicine-infused OVX rats.

\section{Guide Cannula Surgery}

Rats were implanted with a unilateral guide cannula (Plastics One Inc., Roanoke, Va., USA) aimed at the lateral ventricle (coordinates from bregma: anterior $-1.0 \mathrm{~mm}$, lateral $-1.4 \mathrm{~mm}$, ventral $-3.5 \mathrm{~mm}$ from the dura; tooth bar at $-3.3 \mathrm{~mm}$; modified from Paxinos and Watson [31]) for colchicine infusions. The unilateral guide cannulae were implanted using standard stereotaxic procedures $[5,27,32]$. The rats were anesthetized using $2-3 \%$ isoflurane in oxygen and injected with carprofen (s.c. $5 \mathrm{mg} / \mathrm{kg}$ ), an analgesic, prior to surgery. The cannulae were secured to the skull using dental acrylic and stainless steel bone screws. Screw-on headcaps with dummy stylets were inserted into the cannula and projected less than $1.0 \mathrm{~mm}$ past the cannula opening [27]. The rats were housed singly, given oral antibiotics in their drinking water and allowed to recover for 1 week after surgery prior to EB treatments [27].

\section{Steroid Priming}

To test priming effects of estradiol on the expression of PR and $\mathrm{OFQ} / \mathrm{N}$, rats were injected subcutaneously with either $10 \mu \mathrm{g}$ of EB dissolved in $0.1 \mathrm{ml}$ safflower oil or $0.1 \mathrm{ml}$ safflower oil as the control ( $n=5$ per group). Although a priming dose of estradiol $(2 \mu \mathrm{g} \mathrm{EB})$ will induce PR expression, a larger dose and longer exposure of estradiol was given to compensate for the potential that colchicine may reduce the efficacy of EB treatment to induce PR expression.

\section{Microinjection}

To induce accumulation of OFQ/N in the neuronal soma, $4 \mathrm{~h}$ after EB treatment all animals received a lateral ventricular infusion of $50 \mu \mathrm{g}$ of colchicine dissolved in $1.0 \mu \mathrm{l}$ of $0.9 \%$ saline containing $10 \%$ dimethyl sulfoxide [33]. The infusions were performed using an infusion pump (Stoelting Co., Wood Dale, Ill., USA) at a rate of $0.5 \mu \mathrm{l} / \mathrm{min}$ for a total volume of $1.0 \mu \mathrm{l}$ [27]. The microinjection needle projected about $2.0 \mathrm{~mm}$ past the opening of the guide cannula and remained in the guide cannula for approximately $1 \mathrm{~min}$ after completion of infusion to allow the colchicine to diffuse from the injector [27]. After microinjection, headcap stylets were reinserted into the guide cannula, and the animals were returned to their home cages until time of perfusions.

PR and OFQ/N Double-Label Immunohistochemistry

Forty-eight hours after EB treatment, each animal was deeply anesthetized with isoflurane and transcardially perfused with chilled saline followed by perfusion with chilled $4 \%$ paraformaldehyde in Sorensen's phosphate buffer ( $\mathrm{pH} 7.5$ ) [5, 27, 32]. The brains were removed and postfixed overnight in $4 \%$ paraformaldehyde and then cryoprotected by immersion in $20 \%$ sucrose in a $0.1 \mathrm{M}$ phosphate buffer solution $(\mathrm{pH} 7.5)$ and stored at $4^{\circ} \mathrm{C}[2,3]$. Blocked brains were mounted onto a chuck using OCT Tissue-Tek compound (Andwin Scientific, Tryon, N.C., USA) and rapidly frozen by covering in pulverized dry ice. Coronal brain sections $(20$ $\mu \mathrm{m}$ thick) were cut on a cryostat and placed into PBS-filled wells and stored at $4^{\circ} \mathrm{C}$, and the standard series of brain sections was selected at 1:4. 
$\mathrm{PR}$ and $\mathrm{OFQ} / \mathrm{N}$ immunohistochemistry was conducted using a polyclonal $\mathrm{PR}$ antibody raised in rabbit (DAKO, Carpinteria, Calif., USA) that detects the PR isoforms $\mathrm{A}$ and $\mathrm{B}[34,35]$ and a polyclonal OFQ/N antibody (Neuromics Inc., Edina, Minn., USA) raised in guinea pig. All labeling procedures were done at room temperature unless specified otherwise. Free-floating brain sections were washed in PBS followed by incubation in PBS containing $10 \% \mathrm{MeOH}$ and $3 \% \mathrm{H}_{2} \mathrm{O}_{2}$ for 10 min to quench endogenous peroxidase activity. Sections were washed in PBS containing $0.2 \%$ Triton X-100 (TX) and incubated in PBS containing 0.75\% glycine for $30 \mathrm{~min}$, and then incubated in a blocking solution of PBS containing $1 \%$ normal goat serum (NGS) and $1 \%$ bovine serum albumin (BSA) for $30 \mathrm{~min}$. Sections were then incubated for $48 \mathrm{~h}$ at $4^{\circ} \mathrm{C}$ in PBS containing $1 \%$ NGS and the PR antibody $(1: 2,000)$ and then washed 3 times in PBS followed by a wash in Tris-buffered saline (TBS, $\mathrm{pH}$ 7.6). The PR primary antibody was labeled using a biotinylated goat anti-rabbit secondary antibody followed by labeling using fluorescein (FITC) Tyramide Signal Amplification kit (TSA kit, Perkin Elmer, Waltham, Mass., USA [5]). The sections were washed in PBS followed by an incubation in PBS blocking solution containing $1 \%$ NGS, $1 \%$ BSA and $0.5 \%$ TX for 60 min. Sections were then incubated for $48 \mathrm{~h}$ in the blocking solution containing OFQ/N antibody (1:500). OFQ/N primary antibody was visualized by a rhodamine-conjugated goat anti-guinea pig secondary antibody. Sections were rinsed in PBS followed by TBS and were incubated for $2 \mathrm{~h}$ in TBS containing 1\% NGS and secondary antibody (1:200, Jackson ImmunoResearch Laboratories Inc., West Grove, Pa., USA). The sections were rinsed in TBS, transferred to Tris buffer and mounted onto Superfrost Plus slides (Fisher Scientific). Mounted sections were dried on a $37^{\circ} \mathrm{C}$ slide warmer and coverslipped using Aqua-Poly/Mount (Polysciences Inc., Warrington, Pa., USA).

\section{Immunohistochemistry Controls}

The specificity of $\mathrm{PR}$ and OFQ/N antibody immunostaining was determined in a set of tissue sections that were incubated in either $\mathrm{PR}$ or $\mathrm{OFQ} / \mathrm{N}$ primary antibody that had been preabsorbed overnight at $4^{\circ} \mathrm{C}$ with a 10-fold molar excess of the corresponding antibody peptide (PR amino acids 533-547; OFQ/N blocking peptide, Neuromics Inc.). In both sets of controls, no immunoreactive staining patterns were observed.

\section{Analysis}

To confirm colocalization of immunoreactivity for PR and $\mathrm{OFQ} / \mathrm{N}$, the slides were analyzed using an Olympus Fluoview 1000 confocal laser scanning system mounted on an inverted Olympus IX-81 microscope (Olympus America Inc., Center Valley, Pa., USA). Z-stacks were taken through the depth of the tissue within the areas of interest to allow for a three-dimensional reconstruction of neurons to demonstrate whether or not PR and OFQ/N immunoreactivity were colocalized [4]. The confocal was equipped with an argon ion laser with an output of 458, 488, and $515 \mathrm{~nm}$, a green/yellow diode laser with an output of $559 \mathrm{~nm}$, and a red diode laser with an output of $635 \mathrm{~nm}$. FITC was visualized with a 465- to 495-nm emission filter and a 515- to 555-nm bandpass filter, and TRITC was visualized with a 515- to 550-nm emission filter and 600- to 640-nm bandpass filter.

The PR and OFQ/N double immunohistochemical-labeled sections were analyzed using a Zeiss Axioskop 2 epifluorescent microscope equipped with an Axiocam CCD camera, and a digital image analysis system (Carl Zeiss MicroImaging Inc., Thornwood, N.Y., USA). The images were adjusted using the Channel Mixer tool on Adobe Photoshop CS3 (Extended Version 10.0.1; Adobe, San Jose, Calif., USA). Quantitative measurements of PR and $\mathrm{OFQ} / \mathrm{N}$ colocalization were performed by counting the number of cell bodies in the ARH which were immunoreactive for either PR only, OFQ/N only, or both PR and OFQ/N. The ARH was outlined, and the number of PR-immunopositive cells and OFQ/Nimmunoreactive cells in ARH sections along the rostrocaudal axis at the level of the $\mathrm{VMH}$ and median eminence were counted using the National Institute of Health ImageJ software Cell Counter Plug-in (version 1.42; NIH, Bethesda, Md., USA). To avoid double counting of cells, new counts were adjusted using the Abercrombie correction [36] and the total numbers of single-labeled or doublelabeled cell bodies were averaged across animals. In order to determine the proportion of $\mathrm{PR}$ - or $\mathrm{OFQ} / \mathrm{N}$ - immunoreactive neurons that coexpress $P R$ and OFQ/N, a percentage was obtained by dividing the total number of $\mathrm{PR}$ and $\mathrm{OFQ} / \mathrm{N}$ colocalized neurons by either the total number of $\mathrm{PR}$-only or $\mathrm{OFQ} / \mathrm{N}$-only immunoreactive neurons and then multiplying the calculated number by 100 . The data were analyzed by SigmaStat 3.5 (Systat Software Inc., San Jose, Calif., USA) using 2 -tailed t tests, where $\mathrm{p}<0.05$ was considered significant. Arcsin square root transformations were performed on percentage data prior to t test analysis.

\section{Experiment II}

To determine whether a population of ARH neurons projects to the MPN and expresses both POMC (putative $\beta$-END) and ORL-1, OVX rats were injected with 5\% FG into the MPN. One week later, animals were perfused, and brains were collected $24 \mathrm{~h}$ after the third $2 \mu \mathrm{g}$ EB or oil treatment ( $\mathrm{n}=4$ per group). Brains were processed to visualize expression of POMC and ORL-1 mRNA and FG in the ARH.

\section{MPN Fluoro-Gold Injection}

Under isoflurane anesthesia and using standard stereotaxic procedures, a 29-gauge infusion needle was slowly lowered into the MPN [29]. The retrograde tract tracer FG (5\% dissolved in $0.9 \%$ sterile saline) was pressure-injected into the MPN just dorsal to the MPN centralis (MPNc; coordinates from bregma, anterior, -0.1 $\mathrm{mm}$; lateral, $-0.8 \mathrm{~mm}$, and ventral, $-6.0 \mathrm{~mm}$ from dura; tooth bar, $-3.3 \mathrm{~mm}$ [37]) using a Stoelting syringe pump (total volume $1 \mu$; $0.1 \mu \mathrm{l} / \mathrm{min}$ ). The infusion needle was left in place for $10 \mathrm{~min}$ after infusion to allow for diffusion from the tip and then slowly removed from the brain to reduce potential spread of FG (see fig. $4 \mathrm{~g}$, $\mathrm{h})$. The skull was sealed with bone wax and the wound closed with surgical wound clips. Rimadyl (5 mg/kg, s.c.) analgesic was given during the surgical procedure. Topical antibiotic was applied to the wound, and oral antibiotics were given in the drinking water (trimethoprim and sulfamethoxazole; $0.5 \mathrm{mg} / \mathrm{ml}$ ).

\section{Steroid Priming and Tissue Preparation}

Animals received a subcutaneous injection of either EB or oil once every 4 days for 3 cycles. Steroid treatments were timed so that 1 week after FG injection and $24 \mathrm{~h}$ after the final oil or EB injection, the animals were deeply anesthetized with isoflurane and transcardially perfused with chilled $0.9 \%$ saline followed by $4 \%$ paraformaldehyde in Sorensen's phosphate buffer, $\mathrm{pH}$ 7.4. Brains were postfixed overnight in $4 \%$ paraformaldehyde and then cryoprotected by transferring into $20 \%$ sucrose in a $0.1 \mathrm{M}$ phosphate 
buffer solution ( $\mathrm{pH} 7.5$ ) and stored at $4^{\circ} \mathrm{C}$ until sectioning [5]. We chose the 24-hour time point for $\mathrm{EB}$ exposure because in previous studies POMC has been shown to be upregulated at this time point and also is associated with the upregulation of other systems that are important for the facilitation of lordosis such as PR, NPY and ORL-1 [13, 21, 38, 39].

For in situ hybridization, $20 \mu \mathrm{m}$ thick coronal brain sections were collected on a cryostat with RNase-free paint brushes and placed directly into RNase-free 24-well plates containing RNasefree $0.1 \%$ diethylpyrocarbonate (DEPC)-treated PBS, $\mathrm{pH}$ 7.5. Within $48 \mathrm{~h}$, these sections were mounted on Superfrost Plus slides (Fisher Scientific, Pittsburgh, Pa., USA). Mounted sections were dried on a $37^{\circ} \mathrm{C}$ slide warmer overnight and stored desiccated at $-80^{\circ} \mathrm{C}$ until processing. The standard series of brain sections selected for labeling was $1: 4$.

\section{Probe Preparation}

ORL-1 in situ hybridization was performed using the plasmid vector pORL1.1 (courtesy of Dr. J. Boulter, Department of Psychiatry, UCLA) containing a 692-bp cDNA fragment of rat-ORL 1.1 (GenBank accession No. U05239; spanning bases 1-692). POMC in situ hybridization used the plasmid vector pPOMC (courtesy of Dr. Sylvie Jegou, University of Rouen, France) containing a 409-bp cDNA fragment corresponding to the third exon of the POMC gene, position 221-629 which encodes for the neuropeptide $\beta$-END [40]. The cDNA from these plasmids was amplified using M13 forward and M13 reverse primers and gel purified using Epoch Biosystems silica spin columns according to the manufacturer's instructions. The amplified cDNA served as the template for the in vitro transcription reaction in which T7 RNA polymerase (Ambion Inc.) was used to generate the antisense cRNA digoxigenin-11-UTP (DIG)-labeled ORL-1 probe and fluorescein12-UTP (FITC)-labeled POMC probe. T3 RNA polymerase (Ambion Inc.) was used to generate the sense cRNA DIG-labeled ORL1 control probe, and SP6 RNA polymerase (Ambion Inc.) was used to generate the sense cRNA FITC-labeled POMC control probe. Probes were precipitated using $3 \mathrm{M}$ sodium acetate/100\% ethanol $(1: 25 \mathrm{w} / \mathrm{v})$ and reconstituted in $0.1 \%$ DEPC water.

\section{Fluorescent in situ Hybridization}

Mounted tissue was brought to room temperature in sealed boxes containing desiccant. The slides were rehydrated in $0.1 \%$ DEPC PBS for $30 \mathrm{~min}$ and treated with proteinase $\mathrm{K}(10 \mu \mathrm{g} / \mathrm{ml}$, Sigma Aldrich) in $100 \mathrm{~mm}$ Tris- $\mathrm{HCl}$ and $1 \mathrm{~mm}$ EDTA, $\mathrm{pH}$ 8.0, for $10 \mathrm{~min}$ at $37^{\circ} \mathrm{C}$ while stirring to increase probe penetration. An incubation of 30 min in $3 \% \mathrm{H}_{2} \mathrm{O}_{2}$ in PBS was used to inhibit endogenous peroxidase activity. The slides were then rinsed in $1 \times$ PBS, washed with $0.1 \mathrm{M}$ triethanolamine (TEA) $\mathrm{pH}$ 8.0, for $5 \mathrm{~min}$, and acetylated with $0.25 \%$ acetic anhydride in $0.1 \mathrm{M} \mathrm{TEA}, \mathrm{pH} 8.0$, for $10 \mathrm{~min}$ while stirring. Slides were then washed in $1 \times \mathrm{PBS} 3$ times for $5 \mathrm{~min}$ each and $2 \times \mathrm{SSC}(0.3 \mathrm{M} \mathrm{NaCl} / 0.08 \mathrm{M}$ sodium citrate; $\mathrm{pH}$ 7.2) for $5 \mathrm{~min}$. Tissue was dehydrated by a graded series of ethanol washes $(50,70,95$, and $100 \%)$ for 2 min each. The slides were air dried for $60 \mathrm{~min}$ and then stored at $-80^{\circ} \mathrm{C}$ in sealed boxes containing desiccant until hybridization. For hybridization, slides were brought to room temperature. Hybridization buffer $(100 \mu \mathrm{l}$ per slide) containing $50 \%$ deionized formamide, $600 \mathrm{mM} \mathrm{NaCl}, 10$ mM Tris- $\mathrm{HCl}$ pH 8.0, $1 \times$ Denhardt's solution, $0.5 \mathrm{mg} / \mathrm{ml}$ yeast $\mathrm{t}$ RNA, $1 \mathrm{mM}$ EDTA, $10 \%$ dextran sulfate, and $0.1 \mu \mathrm{g} / \mathrm{ml}$ of sheared salmon sperm DNA was heated on an $80^{\circ} \mathrm{C}$ heat block for $10 \mathrm{~min}$.
$500 \mathrm{ng}$ of each probe was added to the hybridization buffer and incubated at $80^{\circ} \mathrm{C}$ for $5 \mathrm{~min}$ to denature the probe. Control slides received hybridization buffer with sense probe. The slides were hybridized in a humid hybridization chamber containing $2 \times$ $\mathrm{SSC} / 50 \%$ formamide at $63^{\circ} \mathrm{C}$ for $16 \mathrm{~h}$. Coverslips were individually removed by soaking in $5 \times \mathrm{SSC}$ prewarmed to $65^{\circ} \mathrm{C}$. The slides were then washed in $2 \times \mathrm{SSC} / 50 \%$ formamide at $65^{\circ} \mathrm{C}$ for $30 \mathrm{~min}$, then transferred to a TNE (10 mM Tris- $\mathrm{HCl} \mathrm{pH} \mathrm{7.5,} 500 \mathrm{nM} \mathrm{NaCl}$, $1 \mathrm{~mm}$ EDTA) wash for $10 \mathrm{~min}$ at $37^{\circ} \mathrm{C}$ with gentle agitation. To remove any unbound probe, the slides were treated with $20 \mu \mathrm{g} / \mathrm{ml}$ RNase $\mathrm{A}$ in TNE at $37^{\circ} \mathrm{C}$ for $30 \mathrm{~min}$ followed by a subsequent 10 min TNE wash at $37^{\circ} \mathrm{C}$. Afterwards, sections were washed in $2 \times$ SSC, $1 \times$ SSC, and $0.5 \times$ SSC each for $20 \mathrm{~min}$ at $65^{\circ} \mathrm{C}$ while stirring.

Fluorescent detection of hapten-labeled probes with DIG and FITC was performed by immunohistochemistry. For double-label FISH, the ORL-1 DIG-labeled probe was detected with anti-DIG antibody (Roche Molecular Biochemicals, Mannheim, Germany) raised in sheep, followed by a rabbit anti-sheep antibody conjugated to DyLight 649 (Jackson Immunoresearch, West Grove, Pa., USA); POMC FITC-labeled probe was detected by anti-FITC monoclonal IgG subclass 1 antibody (Roche Molecular Biochemicals) raised in the mouse, followed by a goat anti-mouse IgG, Fc $\gamma$ subclass 1 specific antibody conjugated to DyLight 488 (Jackson Immunoresearch, West Grove, Pa., USA). The tissues were equilibrated in TBS for $10 \mathrm{~min}$ followed by a 60 -min block in $1 \%$ Blocking Reagent (Roche Molecular Biochemicals) and a 60-min block in TBS containing $1 \%$ normal rabbit serum, $1 \%$ BSA, and $1 \%$ TX. Next, the slides were incubated with a 1:200 dilution of sheep antiDIG in TBS block at $4^{\circ} \mathrm{C}$ for $42 \mathrm{~h}$ in a dark humid chamber. All following steps were carried out in the dark to avoid bleaching fluorescent signal. Three 20-min washes in block were followed by an incubation with secondary antibody (1:200 rabbit anti-sheep DyLight 649) for $2 \mathrm{~h}$ in a humid chamber for detection of ORL-1. Three washes in block for 10 min were followed by 3 TBS 10 min washes and a 60 min TBS block containing $1 \%$ NGS, $1 \%$ BSA, and $1 \%$ TX. Next, the slides were incubated with a 1:100 dilution of anti-FITC monoclonal IgG, Fc $\gamma$ subclass 1 primary antibody in TBS block at $4^{\circ} \mathrm{C}$ for $42 \mathrm{~h}$ in a dark humid chamber. Three 20 -min washes in block followed to wash off unbound primary antibody from the slides. Incubation in the appropriate secondary antibody for $2 \mathrm{~h}$ was performed in a humid chamber for detection of POMC. Three washes in block for $10 \mathrm{~min}$ were followed by 310 -min TBS washes, 2 TNT $(0.05 \%$ Tween 20 in TN buffer) washes 10 min each, and rinsed in $0.1 \mathrm{M}$ Tris- $\mathrm{HCl} \mathrm{pH} \mathrm{7.5.} \mathrm{The} \mathrm{slides} \mathrm{were} \mathrm{then} \mathrm{dried} \mathrm{on}$ a $37^{\circ} \mathrm{C}$ slide warmer and coverslipped using Aqua-Poly/Mount (Polysciences, Warrington, Pa., USA).

\section{POMC/ORL-1 FISH and FG Analysis}

Colocalization was determined using the Leica DM6000 epiluminescent microscope, Leica DFC 360FX monochrome digital camera, and Leica AF-LAS microscope software to detect POMC, ORL-1, and FG through the use of FITC, Cy5, and FG filter cubes, respectively. POMC mRNA was visualized by FITC imaging at a 488-nm emission filter and a 515- to 540-nm bandpass filter. ORL1 mRNA was visualized using a 649-nm emission filter and a 620to 660 -nm bandpass filter. FG was visualized using a wide-band ultraviolet excitation filter (excitation $331 \mathrm{~nm}$, emission $418 \mathrm{~nm}$ at neutral $\mathrm{pH}$ ). Images were adjusted for brightness and contrast using Adobe Photoshop (version 7.0). Files were imported to Image for quantitative analysis of colocalization. The cell counter on Im- 
ageJ was used to count numbers of cells that express cytoplasmic staining for ORL-1 or POMC alone within the ARH between breg$\mathrm{ma}-1.72$, the rostral most portion of the ARH, extending to -2.52 , the most caudal retrochiasmatic portion of the ARH where FGlabeled cells were observed [31]. This portion of the ARH corresponds to area 1 from Cheung and Hammer [18].

The comparison of EB versus oil treatment on the number of ARH neurons that were positively single-, double- or triple-labeled for FG staining, POMC, or ORL-1 mRNA expression were analyzed by Student's t test. The number of neurons in the ARH that colocalized POMC and ORL-1 mRNA was determined in EB- and oil-treated rats, and the percent of cells within each population that expressed the other mRNA was determined. The effects of EB compared to oil treatment on (1) the number of cells that coexpressed POMC and ORL-1 mRNA, (2) the percent of POMC cells that expressed ORL-1 mRNA, and (3) the percent of ORL-1 cells that expressed POMC mRNA were analyzed by Student's t test (SigmaStat version 3.5). Similarly, Student's t test was used to analyze the effects of EB on the number of triple-labeled cells and the percent of each triple-labeled cell population of (1) POMC, (2) ORL-1 and (3) FG.

\section{Experiment III}

To confirm the estradiol increase in ORL-1 expression in the ARH, ORL-1 protein levels were measured in whole tissue preparation of the ARH. As in experiment II, rats received either $2 \mu \mathrm{g}$ EB $(n=6)$ or oil $(n=5)$ treatments for three cycles once every 4 days, and $24 \mathrm{~h}$ after the third treatment the animals were deeply anesthetized with isoflurane and killed by decapitation.

\section{Western Blot}

Protein analysis and ARH block dissection were performed as described in Mahavongtrakul et al. [41]. Briefly, brains were quickly removed from the cranium, chilled in $4^{\circ} \mathrm{C}$ PBS, and block dissections of the ARH $2 \mathrm{~mm}$ thick were collected into 1.5-ml Eppendorf tubes. The tissue was then flash frozen in a dry ice and ethanol bath and stored at $-80^{\circ} \mathrm{C}$ until processing. To extract total protein, the ARH tissues were individually homogenized in $2 \times$ gel-loading buffer [GLB; $0.5 \mathrm{M}$ Tris, $\mathrm{pH} 6.8,10 \% \mathrm{w} / \mathrm{v}$ sodium dodecyl sulfate (SDS), 20\% glycerol] containing a 1:10 dilution of protease inhibitor cocktail (Sigma-Aldrich) and a 1:100 dilution of phenylmethanesulfonyl fluoride (Sigma-Aldrich) using a glass tissue grinder (Kimble Chase). A bicinchoninic acid assay (Thermo Pierce) was performed followed by UV-visible spectroscopy (Bio-Rad) at 562 $\mathrm{nm}$ to calculate total protein concentration. Total protein $(20 \mu \mathrm{g})$ was denatured with $5 \% \beta$-mercaptoethanol and loaded onto a SDS-PAGE gel for $1 \mathrm{~h}$ and $20 \mathrm{~min}$ at room temperature. The protein was then transferred onto nitrocellulose membranes by passing $100 \mathrm{~V}$ across the membranes at $4^{\circ} \mathrm{C}$ for $1 \mathrm{~h}$ and $30 \mathrm{~min}$ (BioRad). The membranes were then blocked in $10 \%$ nonfat milk dissolved in $1 \times$ TBS with Tween-20 (TBST) overnight at $4^{\circ} \mathrm{C}$ on an orbital shaker. The following day, the membranes were incubated overnight at $4{ }^{\circ} \mathrm{C}$ on an orbital shaker in one of two primary antibodies: rabbit anti-nociceptin receptor (1:1,000; Abcam) or mouse anti- $\beta$-actin (1:100,000 in 3\% nonfat milk; Sigma-Aldrich). Then, the membranes were washed 3 times for $10 \mathrm{~min}$ each with $1 \times$ TBST, followed by a 45 -min incubation at room temperature on an orbital shaker in either affinity-purified peroxidase-conjugated goat anti-rabbit (1:10,000; Sigma-Aldrich) or rabbit anti-mouse (1: 50,000; Sigma-Aldrich) secondary antibodies. This was followed by 3 washes with $1 \times$ TBST for 20 min each. The membranes were then incubated in West Pico chemiluminescent substrate (1:1 ratio of luminol:peroxide) for $5 \mathrm{~min}$ and then imaged using Biomax light film in the dark to visualize bands (Thermo Scientific).

\section{Analysis}

Densitometry of the Western blots was obtained using a Gel Doc $^{\text {TM }}$ XR charged-coupled device camera and the Quantity One software (Bio-Rad). ORL-1 bands were normalized to $\beta$-actin. For each of the treatment groups, a mean normalized density was calculated. Then, the normalized densities were divided by the mean normalized density, resulting in a normalized mean of 1.0 for oil controls. The normalized densities for oil and $2 \mu \mathrm{g}$ EB were compared to one another using Student's t test with a significance threshold of $\mathrm{p}<0.05$ (SigmaStat 3.5).

\section{Results}

\section{Experiment I: Estradiol Regulation of PR and OFQ/N}

Expression in the ARH

Within the ARH, populations of neurons were immunopositive for PR only, OFQ/N only, $\mathrm{PR}$ and $\mathrm{OFQ} / \mathrm{N}$, or not stained for either PR or OFQ/N (fig. 2). OFQ/N-immunopositive neurons were observed in the dorsomedial to the ventrolateral ARH (fig. 2a, d). The red fluorescent immunolabeling for the ligand $\mathrm{OFQ} / \mathrm{N}$ was localized in the cytoplasm of the soma and some neural processes in colchicine-treated rats (fig. 2a, d). Neurons that were immunopositive for both PR and OFQ/N had either green fluorescent PR labeling in the nucleus surrounded by red fluorescent $\mathrm{OFQ} / \mathrm{N}$ labeling in the soma and processes, or green and red labeling within the cytoplasm (fig. 2c, f). Colocalization of $\mathrm{PR}$ and $\mathrm{OFQ} / \mathrm{N}$ immunoreactivity was confirmed by confocal microscopic three-dimensional reconstructions through the depth of the tissue (fig. 2g, h).

PR-immunopositive neurons were observed in the medial portion of the ARH and decreased in number towards the dorsomedial and ventrolateral regions of the ARH (fig. 2b, e). In estradiol-treated rats, immunopositive green fluorescent staining for PR was mainly localized in the nucleus of neurons (fig. 2e, g, h). In contrast, immunopositive staining for PR in the oil-treated control rats was observed both in the cytoplasm of some neurons and the nucleus of others (fig. 2b).

EB treatment significantly increased the number of OFQ/N-immunopositive neurons by 1.62 -fold (fig. 3a; $\mathrm{t}$ test, d.f. $=8, \mathrm{t}=11.21, \mathrm{p}<0.001$ ). The number of PRimmunopositive neurons was significantly increased by 2.48-fold in EB-treated rats compared to oil-treated control animals (fig. 3a; $\mathrm{t}$ test, d.f. $=8, \mathrm{t}=10.283, \mathrm{p}<0.001$ ). 


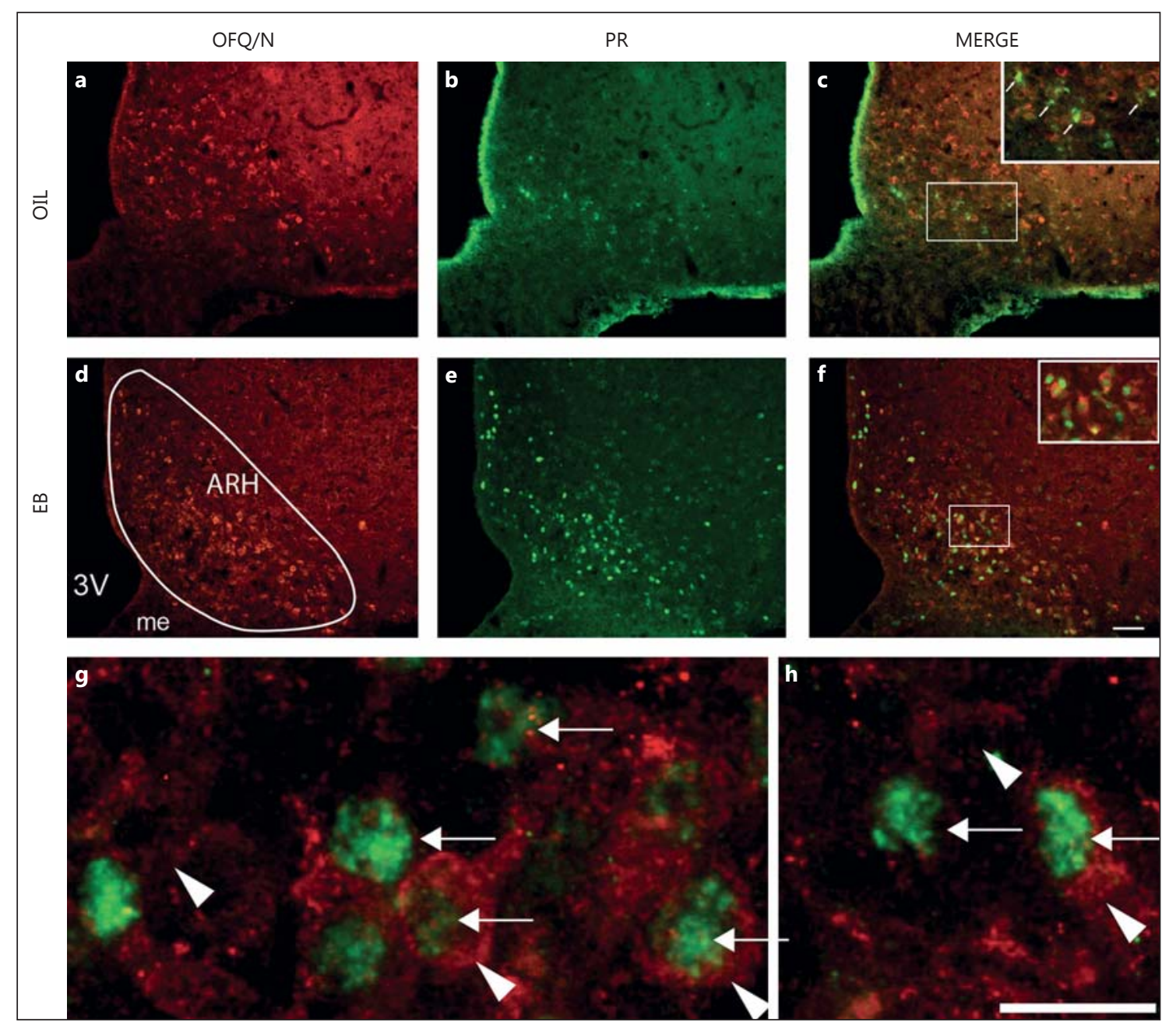

Fig. 2. Photomicrographs of $P R$ and $O F Q / N$ double-label immunohistochemistry in the ARH. Colchicine-treated OVX rats were given either $10 \mu \mathrm{g}$ EB or safflower oil (OIL), and tissue was collected $48 \mathrm{~h}$ later for immunohistochemistry. a, d TRITC labeling of OFQ/N immunoreactivity (red) is mainly localized to the cytoplasm of ARH neurons. b, e FITC labeling of PR (green) is mainly localized to the nucleus of EB-treated animals, whereas in oil-treated animals both nuclear and extranuclear staining was observed. c, $\mathbf{f}$ A subpopulation of neurons was labeled with both PR and $\mathrm{OFQ} / \mathrm{N}$ immunoreactivity (green, red; indicated by arrowheads in photomicrographs of EB-treated rats). c Inset illustrates a higherpower view of PR immunostaining that appears extranuclear (arrows). f Inset illustrates a higher-power view of the different popu-

Subpopulations of ARH neurons were immunopositive for both $\mathrm{PR}$ and $\mathrm{OFQ} / \mathrm{N}$, and $\mathrm{EB}$ treatment significantly increased the number of these neurons (fig. $3 \mathrm{~b}$; t test, d.f. $=8, \mathrm{t}=7.43, \mathrm{p}<0.001)$. The percentage of $\mathrm{PR}$-immunopositive cells that colocalized with $\mathrm{OFQ} / \mathrm{N}$ immunoreactivity in the ARH was not significantly increased with estradiol lations of immunostained cells counted. $\mathbf{d}$ The area outlined is representative of the area counted for each section of the ARH. me = Median eminence; $3 \mathrm{~V}=$ third ventricle. Scale bar $=30 \mu \mathrm{m} . \mathbf{g}$, h Confocal Z-stack reconstruction photomicrographs of PR and $\mathrm{OFQ} / \mathrm{N}$ double-label immunohistochemistry in the ARH of estradiol- and colchicine-treated OVX rats. FITC labeling of PR immunoreactivity (arrows; green) was mainly localized to the nucleus of neurons. TRITC labeling of OFQ/N immunoreactivity was localized to the cytoplasm and extended into some neuronal processes (arrowheads; red). A subpopulation of neurons was labeled with both PR and OFQ/N immunoreactivity (arrows and arrowheads), and others were only labeled with either OFQ/N or PR immunoreactivity or had no labeling. Scale bar $=10 \mu \mathrm{m}$. treatment (fig. $3 c$; $\mathrm{t}$ test, d.f. $=8, \mathrm{t}=-1.219, \mathrm{p}=0.258$ ). In contrast, the percentage of $\mathrm{OFQ} / \mathrm{N}$-immunopositive cells that expressed PR immunoreactivity in the ARH was significantly increased with estradiol treatment (fig. $3 \mathrm{~d}$; $\mathrm{t}$ test, d.f. $=8, \mathrm{t}=4.014, \mathrm{p}=0.004$ ). 
As in the ARH, subpopulations of neurons within the MPN, anteroventral periventricular nucleus (AVPV) and posterodorsal medial amygdala were observed to be immunopositive for both PR and OFQ/N (not shown).

\section{Experiment II: FISH Visualization of ORL-1 mRNA Expression in POMC ARH Neurons That Project to the MPN}

To determine whether ORL-1 are expressed in POMC neurons that project to the MPN, the retrograde tract tracer FG was injected into the MPN dorsal to the MPNc in OVX rats treated with either EB or oil, and tissue sections through the ARH were processed for ORL-1 and POMC mRNA expression by FISH. Positive POMC fluo- rescent mRNA staining was colorized green, and positive ORL-1 FISH mRNA fluorescent staining was computercolorized red (fig. 4a, b). Both ORL-1 and POMC mRNA expression were observed in the perikarya. Retrogradely transported FG filled the soma and some processes with fluorescent staining (blue; fig. 4c). Colocalization analysis in the ARH revealed seven labeled populations of neurons: single-labeled for either POMC, ORL-1, or FG only; double-labeled for POMC-ORL-1, POMC-FG, or ORL1-FG; triple-labeled for POMC, ORL-1 and FG (fig. 4), as well as nonlabeled neurons. A subpopulation of ARH neurons were triple-labeled (fig. $4 \mathrm{~d}$ ), supporting the hypothesis that ORL- 1 are expressed in $\beta$-END neurons that project to the MPN.
Fig. 3. Expression and colocalization of $\mathrm{OFQ} / \mathrm{N}$ and $\mathrm{PR}$ in the ARH $48 \mathrm{~h}$ after safflower oil (OIL) or EB treatment in colchicine-treated OVX rats. a Number of neurons that were immunopositive for $\mathrm{OFQ} / \mathrm{N}$ or PR. b Number of neurons that were PRand $\mathrm{OFQ} / \mathrm{N}$-immunopositive. c Percentage of PR-immunopositive neurons that were $\mathrm{OFQ} / \mathrm{N}$ immunopositive. d Percentage of $\mathrm{OFQ} / \mathrm{N}$-immunopositive neurons that were $\mathrm{PR}$ immunopositive. ${ }^{*} \mathrm{p}<$ 0.01 , significantly greater than OIL treatment within immunohistochemical staining group ( $\mathrm{t}$ test).

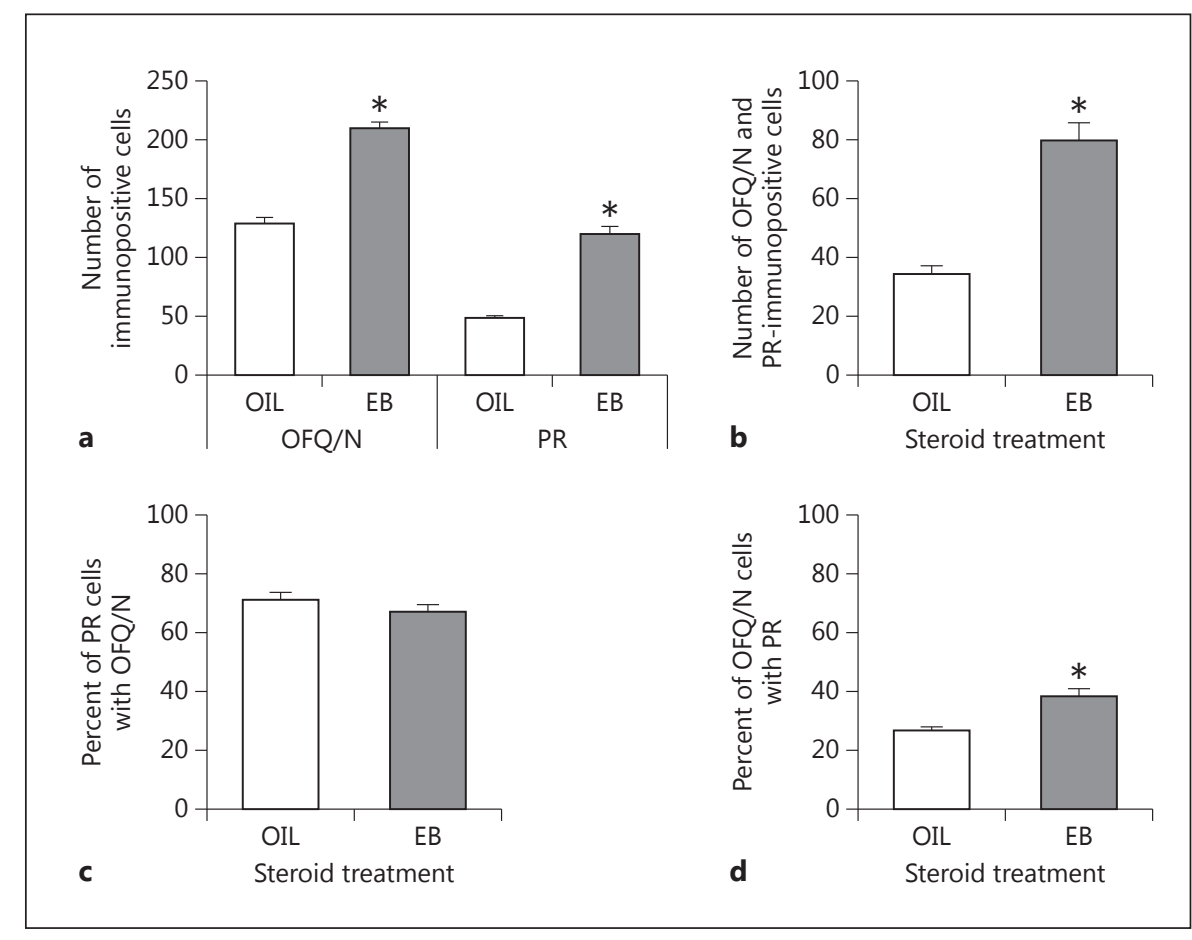

Fig. 4. Photomicrographs of FISH-labeled mRNA for POMC, ORL-1, and retrogradely labeled FG-positive cells and their coexpression in ARH neurons in EB-treated OVX rats. a POMC mRNA FITC-positive labeled cells (green) in the ARH. b ORL-1 mRNA Dy-light 649-positive-labeled neurons (red) in the ARH. c FGfilled neurons (teal-blue) within the ARH from FG infusion in the MPN. d Merged image of $\mathbf{a}-\mathbf{c}$ showing triple-labeled POMC and ORL-1 mRNA-positive, and FG-labeled neurons in EB-treated groups indicating that ORL-1 is expressed in POMC (potential $\beta$-END) neurons that project to the MPN. Subpopulations of ARH neurons: closed arrowhead, neurons expressing POMC, ORL-1, and FG; open arrowhead, neurons expressing FG only; arrow with double open arrowhead, neurons expressing POMC and FG; arrow with closed arrowhead, neurons expressing POMC and ORL1; arrow with open arrowhead, neurons expressing ORL-1 and FG; chevron, neurons expressing ORL-1. e POMC sense control tissue at the level of the ARH. f ORL-1 sense control tissue at the level of the ARH. g, $\mathbf{h}$ Maps of representative spread of FG for injections aimed at the MPN at the level of the MPNc. d Scale bar $=10 \mu \mathrm{m}$. f Scale bar $=50 \mu \mathrm{m}$. aco $=$ Anterior commissure; $\mathrm{c}=$ central; $\mathrm{l}=$ lateral; $\mathrm{m}=$ medial; $\mathrm{MPO}=$ medial preoptic area opt $=$ optic tract; $\mathrm{SCH}=$ suprachiasmatic nucleus; $\mathrm{AP}=$ anterior/posterior coordinates from bregma (mm). Modified from Swanson [84].

(For figure 4 see next page.) 


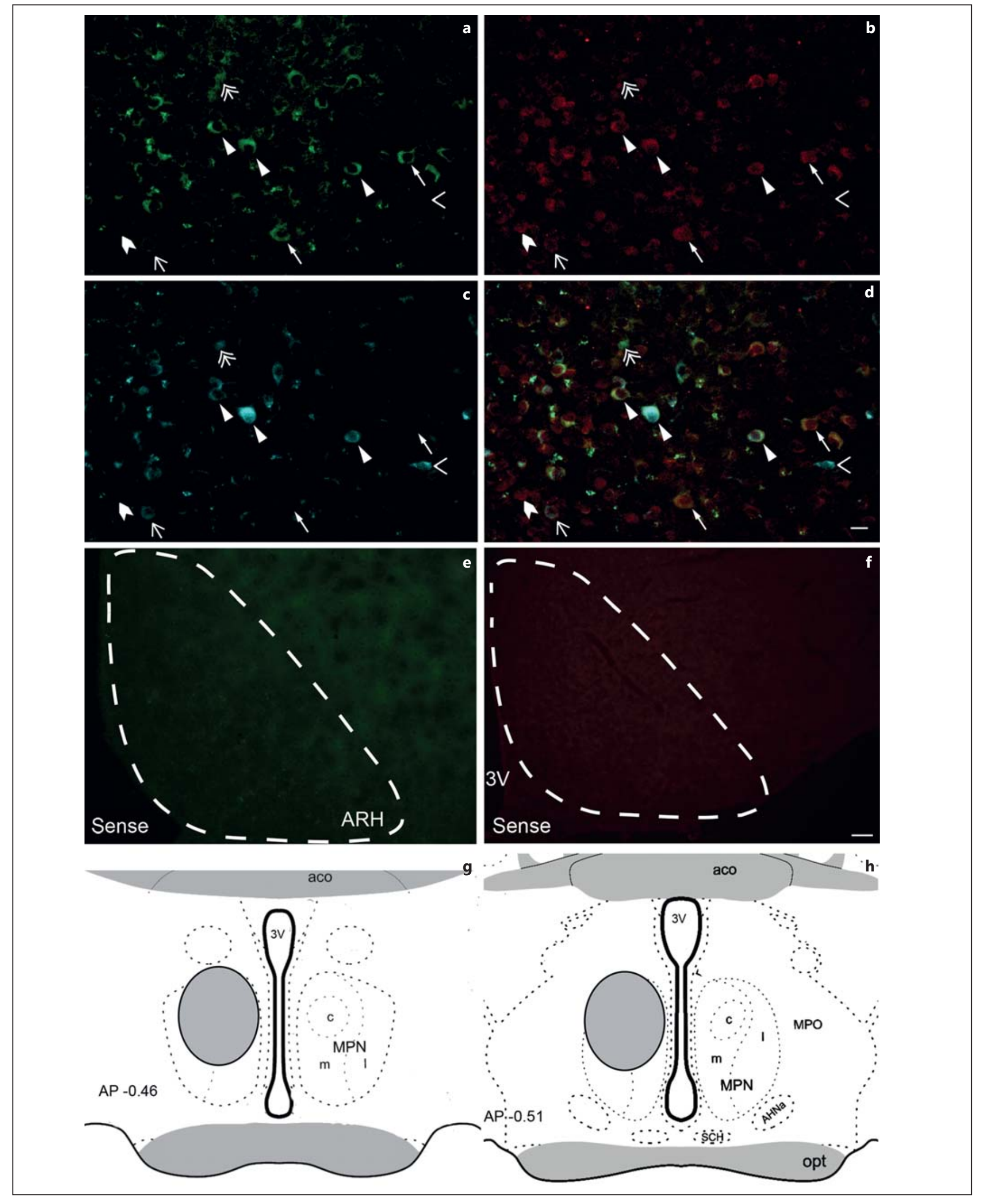




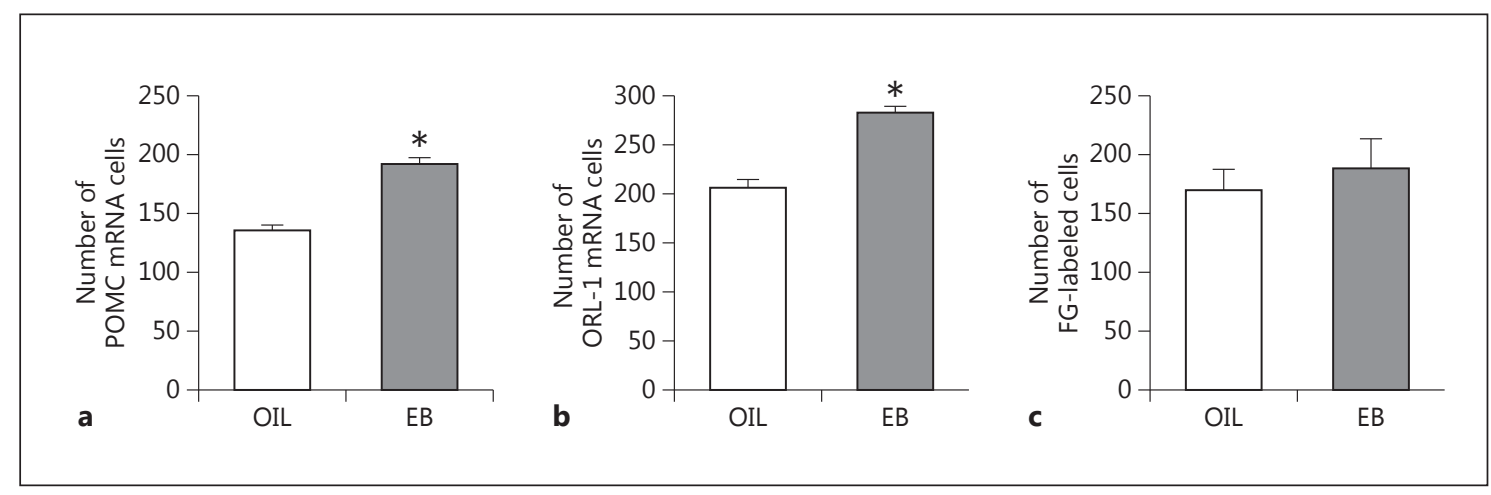

Fig. 5. Estradiol $(2 \mu \mathrm{g}$ EB, s.c. 24 h) treatment increases the number of neurons in the ARH that express POMC mRNA (a) or ORL-1 mRNA (b) FISH labeling compared to vehicle-treated (OIL) animals. c The number of ARH neurons that were labeled by FG MPN infusions was not affected. ${ }^{*} \mathrm{p}<0.01$, significantly greater than OIL treatment ( $\mathrm{t}$ test).

Distribution of POMC mRNA-Expressing Neurons

FISH-labeled POMC mRNA expression was localized to neurons in the ARH and median eminence. In the ARH, POMC mRNA was expressed along the third ventricle in a dorsal-to-ventral pattern and a medial-to-lateral pattern along the ventral extent of the ARH. Although the median eminence contains few neuronal cell bodies, POMC mRNA expression was observed in neurons as reported previously [18]. Fluorescent-labeled POMC sense probe produced minimal nonspecific staining in the ARH (fig. 4e).

Distribution of ORL-1 mRNA-Expressing Neurons

FISH-labeled ORL-1 mRNA expression was widespread within the rat brain and observed throughout the hypothalamus, as reported previously [21, 42]. ORL-1 mRNA expression was observed in ARH, VMH, dorsal medial hypothalamus, posterodorsal medial amygdala, cortex, and hippocampus. FISH ORL-1 mRNA labeled all regions of the $\mathrm{VMH}$ and exhibited a similar intense staining pattern in the ventrolateral portion of the VMH. Fluorescent-labeled ORL-1 sense probe produced minimal nonspecific staining in the ARH and VMH (fig. 4f).

\section{ARH Neurons Projecting to MPN}

MPN FG injections produced FG-filled somas observed in various regions with known projections to the MPN (e.g. ARH, VMH, and posterodorsal medial amygdala [41]). FG retrograde labeling was observed through the rostrocaudal extent of the ARH as reported previously [4], primarily in the dorsal to ventral extent of the medial portion of the $\mathrm{ARH}$ as well as the mediolateral extent of the ventral ARH.
Estradiol Increased Number of Neurons That Express POMC and ORL-1 Expression, but Did Not Affect the Projections to MPN

Individually, EB treatment increased the number of ARH neurons that expressed either POMC or ORL-1 mRNA compared to oil-treated controls (fig. $5 \mathrm{a}, \mathrm{b}$; $\mathrm{t}$ test, $\mathrm{p}<0.001$, POMC, d.f. $=6, \mathrm{t}=8.422$; ORL-1, d.f. $=6, \mathrm{t}=$ 7.719). The number of ARH neurons that project to MPN was not affected by EB treatment (fig. $5 c$; $t$ test, $p=0.561$, d.f. $=6, t=0.615$ ).

Distribution of POMC and ORL-1 Double-Labeled

Neurons

Neurons that stained positively for mRNA of both POMC and ORL- 1 were present mainly in the dorsal ventral aspect of the ARH along the third ventricle. The distribution of double-labeled cells was similar to the POMC distribution since fewer cells expressed POMC.

Distribution of Triple-Labeled POMC and ORL-1

Neurons Projecting to the MPN

A subpopulation of POMC-ORL-1 mRNA-expressing neurons project to the MPN as indicated by the observation of ARH neurons triple-labeled with staining for FG, POMC mRNA and ORL-1 mRNA (fig. 4d). The distribution of triple-labeled cells (ORL-1/POMC neurons projecting to the MPN) within the ARH was mainly in the dorsal ventral aspect of the ARH along the third ventricle similar to that of double-labeled POMC- and ORL-1-expressing neurons. Because the FG probably did not perfuse the entire dorsal MPN region and not every POMC neuron terminal in the MPN took up FG, it is likely that 


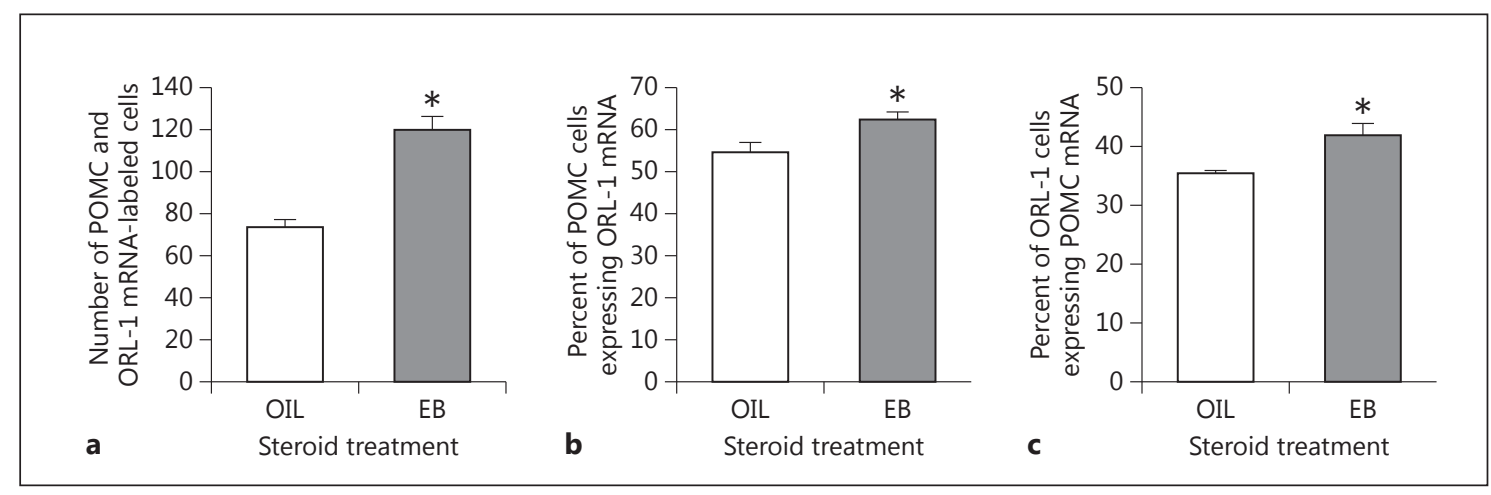

Fig. 6. Effects of estradiol $(2 \mu \mathrm{g} E B)$ treatment on the number of POMC and ORL-1 mRNA double-labeled neurons in the ARH (a), the percent of POMC ARH neurons that express ORL-1 mRNA (b), and the percent of ORL-1 ARH neurons that express POMC mRNA (c). EB increased the number of ARH neurons that expressed POMC and ORL-1 mRNA compared to vehicle-treated
(OIL) rats. Estradiol also increased the percent of POMC population of neurons that expressed ORL-1 mRNA as well as the percent of ORL-1 population of neurons that expressed POMC mRNA compared to OIL-treated rats. ${ }^{*} \mathrm{p}<0.01$, significantly greater than vehicle-treated OIL rats ( $\mathrm{t}$ test). the triple-labeled cell counts underestimate the absolute number of POMC neurons expressing ORL-1 that project to the MPN.

Estradiol Increased ORL-1 and POMC mRNA

Expression in ARH Neurons That Project to MPN

Estradiol increased the number of ARH neurons with coexpression of POMC and ORL-1 mRNA (fig. 6a; t test, d.f. $=6, t=6.691, p<0.001)$. The percentage of POMC mRNA cells expressing ORL- 1 in the ARH was significantly increased by EB treatment (fig. $6 \mathrm{~b}$; t test, d.f. $=6$, $\mathrm{t}=2.530, \mathrm{p}=0.045$ ), as was the percentage of ORL-1 that expressed POMC mRNA (fig. 6 ; t test, d.f. $=6, t=3.485$, $\mathrm{p}=0.013$ ). In both oil- and EB-treated rats, over $50 \%$ of the POMC cells expressed ORL-1 mRNA, whereas less than $40 \%$ of ORL- 1 cells in both treatment groups expressed POMC mRNA (fig. 6b, c). This is most likely due to more ORL-1 mRNA-expressing cells than POMC cells in the ARH (fig. 5a, b).

EB treatment increased the number of ORL-1 mRNA and POMC mRNA neurons that project to the MPN compared to oil-treated controls (fig. 7a; t test, d.f. $=6$, $t=3.405, p=0.014)$. Furthermore, the percentage of FG cells in the ARH that expressed POMC and ORL-1 mRNA was also increased by EB compared to oil (fig. 7b; t test, d.f. $=6, t=2.733, p=0.034$ ). However, estradiol did not alter either the percentage of POMC cells that express ORL- 1 and project to the MPN (fig. $7 \mathrm{c}$; $\mathrm{t}$ test, d.f. $=6, \mathrm{t}=$ $0.948, p=0.380$ ), or the percentage of ORL-1-labeled cells that contain POMC that project to the MPN (fig. $7 \mathrm{~d}$; $t$ test, d.f. $=6, t=1.367, p=0.221)$. These data indicate that estradiol increases the total number of neurons that express POMC and ORL-1 mRNA in ARH neurons within the subpopulation of neurons that project to the MPN.

\section{Experiment III: Estradiol Regulation of ORL-1 Protein} Levels in the $A R H$

To confirm the estradiol-induced expression of ORL-1 mRNA in experiment II, Western blot analysis of whole tissue from ARH block dissections in estradiol- and oiltreated OVX rats was performed. Normalized to $\beta$-actin, ORL- 1 levels were increased $24 \mathrm{~h}$ after $2 \mu \mathrm{g}$ EB compared to the oil controls (fig. 8; t test, d.f. $=10, \mathrm{t}=-2.322, \mathrm{p}=$ 0.043).

\section{Discussion}

The present anatomical studies demonstrate that estradiol upregulates OFQ/N-ORL-1 and POMC systems in the ARH and in a subset of these neurons that project to the MPN. Estradiol upregulates the number of ARH neurons that (1) express PR and OFQ/N as well as their coexpression, and (2) express ORL-1 and POMC which project to the MPN and their coexpression. In general, our results show that estradiol upregulates the OFQ/NORL-1 system in the ARH that can directly regulate the activity of ARH POMC neurons. These systems within the ARH that project to the MPN may be associated with the regulation of sexual receptivity, whereas other POMC 
Fig. 7. Effects of estradiol $(2 \mu \mathrm{g} \mathrm{EB})$ on a the number of POMC and ORL-1 mRNA-expressing $\mathrm{ARH}$ neurons that project to the MPN (FG labeled), $\mathbf{b}$ the percentage of FGlabeled neurons that are triple labeled, $\mathbf{c}$ the percentage of POMC mRNA-expressing neurons that are triple labeled, and $\mathbf{d}$ the number of ORL-1 mRNA-expressing neurons that are triple labeled. EB increased the number of POMC and ORL-1 mRNAexpressing neurons that project to the MPN compared to vehicle (OIL)-treated rats. However, estradiol did not alter the percent of either c POMC triple-labeled neurons or d ORL-1 triple-labeled neurons. ${ }^{*} \mathrm{p}<0.01$, significantly greater than OIL treatment ( $\mathrm{t}$ test).
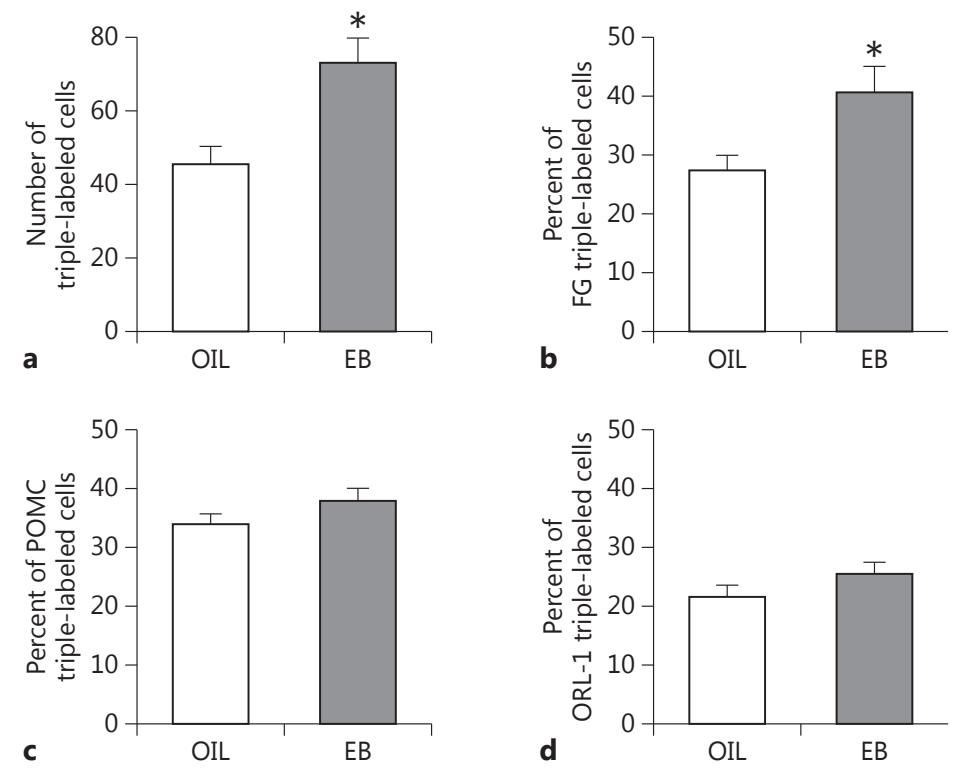

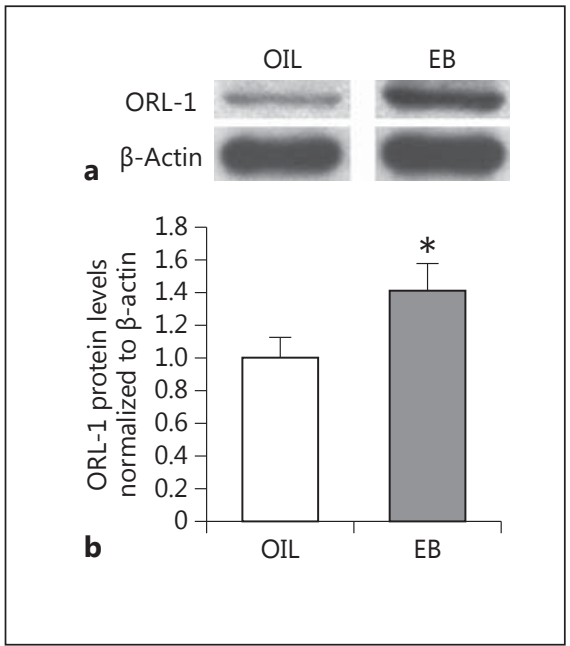

Fig. 8. Western blot analysis of estradiol regulation of ORL-1 protein levels in the ARH. a Representative Western blot of $20 \mu \mathrm{g}$ total protein of ARH. Whole tissue preparations were loaded onto a SDS-PAGE gel and probed for ORL-1. ORL-1 levels were normalized to $\beta$-actin. b Graphical representation of ORL-1 protein levels in the ARH. Twenty-four hours after $2 \mu \mathrm{g}$ EB (EB), whole tissue ORL-1 protein levels were increased in the ARH compared to oiltreated (OIL) OVX rats. ${ }^{*} \mathrm{p}<0.05$, significantly greater than oil treatment ( $\mathrm{t}$ test). neurons may be regulating energy balance and luteinizing hormone (LH) release [reviewed in 1].

Using double-label immunohistochemistry for PR and $\mathrm{OFQ} / \mathrm{N}$, we demonstrated that $48 \mathrm{~h}$ after estradiol treatment the number of $\mathrm{PR}$ - and $\mathrm{OFQ} / \mathrm{N}$-immunopositive neurons in the ARH is increased as well as their coexpression. This subpopulation of neurons with $\mathrm{PR}$ and $\mathrm{OFQ} / \mathrm{N}$ suggests a potential mechanism for direct regulation of $\mathrm{OFQ} / \mathrm{N}$ release by progesterone. In the ARH-MPN lordosis model circuit, a subset of these ARH-PR-OFQ/N neurons is hypothesized to synapse upon $\beta$-END-ORL-1 neurons (fig. 1). Given that numerous ARH neurons project to the MPN, it is possible that some of these PROFQ/N neurons may project to the MPN and are responsible for OFQ/N facilitation of lordosis in the MPN (fig. 1) [27]. Colocalization of $\mathrm{PR}$ and $\mathrm{OFQ} / \mathrm{N}$ in $\mathrm{ARH}$ neurons has been shown in the ewe [43], and in other species estradiol has been shown to increase PR expression in the ARH [24-26]. However, this is the first study to demonstrate estradiol upregulation of their coexpression. These results support our hypothesis that estradiol priming increases the ability of progesterone to directly regulate OFQ/N neurotransmission.

Estradiol doubled the population of neurons that were immunopositive for $\mathrm{PR}$ and $\mathrm{OFQ} / \mathrm{N}$, indicating an increase in the responsiveness of this circuit to progesterone. This upregulation of OFQ/N by estradiol increases 
the number of ARH neurons that could inhibit the activity of POMC ( $\beta$-END) neurons that project to the MPN and regulate lordosis or those that project to other brain regions to regulate energy balance and feeding [reviewed in 1]. Subsequent progesterone or longer exposure to high levels of estradiol may be acting through these $\mathrm{OFQ} / \mathrm{N}$ neurons to decrease estradiol-induced POMC neuronal activity [reviewed in 1].

Although estradiol increases $\mathrm{OFQ} / \mathrm{N}$ expression, initially it is not released [21] since ARH-VMH infusions of $\mathrm{OFQ} / \mathrm{N}$ rapidly induces sexual receptivity and deactivates MPN MOP in EB-primed nonreceptive OVX rats [5, 23, 27]. However, a high dose of EB (5-50 $\mu \mathrm{g})$ does eventually stimulate the release of $\mathrm{OFQ} / \mathrm{N}$ that is required for facilitation of lordosis $[5,27]$. Thus, the release of OFQ/N is dependent on the dose of estradiol.

Estradiol also increased POMC and ORL-1 mRNA expression and their coexpression in ARH neurons and in a subpopulation of ARH neurons that project to the MPN. Previously, estradiol was not observed to increase ARH ORL-1 mRNA expression using radioisotopic methods [21]. The increase in ORL-1 mRNA expression was confirmed by measuring ARH ORL-1 protein levels (experiment III). Our current findings are also supported by estradiol increasing ORL-1 binding sites in the mediobasal hypothalamus $[6,12]$.

The regulation of POMC expression in ARH neurons has been shown to be estradiol dose and time dependent. What appear to be conflicting results on the ovarian steroid regulation of POMC expression are more congruent when considered in context with the steroid priming paradigm, and its effects on inducing sexual receptivity and the $\mathrm{LH}$ surge. In general, $\beta$-END release inhibits both lordosis and $\mathrm{LH}$ release [44]. We observed $24 \mathrm{~h}$ after EB priming that POMC expression is increased in OVX rats. A single dose of estradiol in OVX adult mice has also been shown to increase POMC mRNA levels at 12- and 24-hour intervals [13]. However, in rats implanted subcutaneously with a 2-mm estradiol-filled silastic capsule, no effect of estradiol was observed at $36 \mathrm{~h}$, but $48 \mathrm{~h}$ after treatment POMC mRNA expression increased [18]. The $2 \mu \mathrm{g}$ EB dose primes lordosis circuits, produces prolonged (up to $48 \mathrm{~h}$ ) MPN MOP activation, but neither induces lordosis nor an LH surge in OVX Long Evans rats [5, 23, 45, 46]. The increase in POMC expression observed in the first $24 \mathrm{~h}$ after this priming dose of EB may be a part of the mechanism to maintain a releasable pool of $\beta$-END that produces the extended estradiol inhibition of lordosis [5]. In contrast, higher estradiol doses at $48 \mathrm{~h}$ and sequential estradiol + progesterone treatments reduce MPN MOP activation, facilitate lordosis, induce an LH surge, and appear to downregulate POMC expression in ARH and MPN $\beta$-END levels $[3,5$, 46-49]. This may be a mechanism to reduce $\beta$-END release. POMC mRNA levels vary across the estrous cycle and are lowest just prior to the LH surge and then increase rapidly and remain elevated through the LH surge [50]. This parallels the pattern of MPN MOP activation in the estrous cycle. $\mathrm{MOP}$ activation is lowest on the evening of proestrus when sexual receptivity and the LH surge occur, and increases again on the next morning to terminate sexual receptivity [6]. Estradiol and progesterone replacement studies indicate that estradiol initially increases POMC mRNA expression and then reduces POMC mRNA expression prior to the LH surge [48]. In contrast, progesterone appears to induce the increase in POMC during the surge that may contribute to the releasable pool of $\beta$-END to terminate sexual receptivity on estrus or following progesterone treatment [48].

In the context of the ARH-MPN lordosis circuit (fig. 1), estradiol initially increases excitatory input to the POMC neurons through NPY-Y1 and $\mathrm{GABA}_{\mathrm{B}}$ receptor activation to induce $\beta$-END release which internalizes/activates MPN MOP to inhibit lordosis [1, 4, 32, 51] (fig. 1). Subsequent progesterone or longer exposure to estradiol reduces MPN MOP activation and facilitates lordosis, presumably through the inhibition of $\beta$-END (POMC) neurotransmission $[2,3,5,7,45,52]$. Infusions of $\mathrm{OFQ} / \mathrm{N}$ into the ARH deactivate MPN MOP in estradiol-primed rats and facilitate lordosis $[5,23,27]$. Activation of ORL- 1 in POMC $\left(\beta\right.$-END) neurons produces outward $\mathrm{K}^{+}$currents through GIRK channels that reduce the membrane potential and inhibit neurotransmission [28-30] (fig. 1). The 2 $\mu \mathrm{g}$ EB priming dose initially inhibits lordosis, increases ARH ORL-1 expression and is accompanied by the uncoupling of ORL-1 from the GIRK channel in POMC neurons [29]. This reduces the ability of OFQ/N to inhibit $\beta$-END release in the MPN $[29,30]$ and allows for the maintenance of estradiol-induced excitation of POMC $(\beta$-END) neurons which inhibit lordosis. Steroid treatments that facilitate lordosis reduce MPN MOP activation by recoupling ORL-1 to the GIRK channel and increase $\mathrm{K}^{+}$hyperpolarizing currents to inhibit POMC neuronal transmission $[29,30]$.

$\mathrm{OFQ} / \mathrm{N}$ also acts presynaptically to decrease the activity of POMC neurons. Estradiol and progesterone either enhance or decrease the activity of POMC neurons depending on whether the steroid milieu induces a sexually receptive state or not $[29,30]$. Estradiol reduces the ability of $\mathrm{OFQ} / \mathrm{N}$ to decrease glutamatergic excitatory neurotransmission onto ARH POMC neurons that project to 
the MPN $[29,30]$. Progesterone restores the capability of $\mathrm{OFQ} / \mathrm{N}$ to inhibit excitatory glutamatergic input to POMC neurons [30]. Thus, progesterone acting via OFQ/ $\mathrm{N}$-ORL-1 signaling decreases excitatory input and enhances ORL-1 signaling through GIRK channels on POMC neurons. These actions are part of the mechanism to reduce $\beta$-END release and deactivate MPN MOP and facilitate lordosis [30].

These same actions were also observed in POMC neurons that do not project to the MPN, indicating that the priming dose of $\mathrm{EB}$ acts through the OFQ/N-ORL-1 system to synchronize the effects of ovarian hormones on other systems regulated by ARH POMC neurons. POMC is a prohormone for several neuropeptides and peptide hormones that are responsive to ovarian hormones: a-melanocyte stimulating hormone, adrenocorticotropin hormone, $\gamma$-lipotropin, and corticotrophin-like intermediate lobe peptide $[53,54]$. Therefore, ORL-1 may mediate ovarian hormone regulation of energy balance, feeding and hypothalamic feedback loops in addition to sexual receptivity that are controlled by products of the POMC gene $[1,43,55]$. For example, rising estradiol levels reduce appetite in female rodents [56-60]. In contrast, activation of the OFQ/N-ORL-1 system induces hyperphagia [61-65]. Energy homeostasis may be regulated by estradiol and the OFQ/N-ORL-1 system acting through POMC neurons that project to the paraventricular nucleus of the hypothalamus [55, 61, 66]. Estradiol decreases the ability of OFQ/N to pre- and postsynaptically reduce POMC activity in neurons that do not project to the MPN $[29,30]$ like those that do project to the MPN. This increases POMC neuronal activity to maintain neurotransmission that is inhibitory to food intake [28-30, 55]. Furthermore, $\mathrm{OFQ} / \mathrm{N}$ reduces c-Fos expression in $\alpha$-melanocyte stimulating hormone (POMC) neurons at the end of feeding [67].

Gonadotropin-releasing hormone $(\mathrm{GnRH})$ feedback loops are also modulated by classical endogenous opioid peptides and the OFQ/N-ORL-1 system [43, 44, 68-78]. In vitro, OFQ/N inhibits GnRH release from hypothalamic and mediobasal hypothalamic sections from OVX rats [74, 79]. In female rats treated with estradiol and progesterone, $\mathrm{OFQ} / \mathrm{N}$ infusion into the third ventricle reduced the $\mathrm{LH}$ surge magnitude, but did not eliminate the surge [44]. Since circulating progesterone levels rise concurrently or shortly after the onset of the LH surge in the rodent [8082], progesterone may act to stimulate the release of $\mathrm{OFQ} / \mathrm{N}$ to terminate the surge release of $\mathrm{GnRH}$ and $\mathrm{LH}$. These neurons could receive direct input from $\mathrm{PR}-\mathrm{OFQ} / \mathrm{N}$ neurons located in the AVPV (also known as RP3V), MPN or even a population of ARH PR-OFQ/N neurons. Further, it is possible that ORL-1 activation is compartmentalized within the ARH for ovarian steroids to act through $\mathrm{OFQ} / \mathrm{N}$ to regulate $\beta$-END release that modulates $\mathrm{GnRH}$ release [83]. Like the rodent, infusion of $\mathrm{OFQ} / \mathrm{N}$ into the lateral ventricle of the ewe reduced LH secretion, and appeared to regulate LH pulse frequency and amplitude [73].

In summary, we observed that estradiol increases the number of ARH neurons that coexpress PR-OFQ/N and POMC-ORL-1. Ovarian hormone modulation of preand postsynaptic ORL-1 signaling that regulates neuronal activity of POMC neurons indicates that the OFQ/NORL-1 system could play an important role in synchronizing multiple homeostatic, reproductive and behavioral systems in addition to sexual receptivity that is controlled by products of the POMC gene $[1,55,83]$.

\section{Acknowledgements}

This research was supported by NIH Award Numbers RO1HD058638, CSUPERB Grant, CSULB SCAC, CSULB Start-up (K.S.) CSULB Student Summer Stipend Award (N.M.S. and J.M.). Confocal microscopy was supported by a grant from the National Science Foundation (DBI0722757). We thank Dr. Simon Malcomber, Dr. Paul Micevych, Dr. Paul Popper, Asma Mana, Martin Vignovich, Jessica Phillips, Kirstin Fuentes, Bertha Garcia, Robyn Bowlby, and Pamela Charukulvanich for technical assistance.

\section{References}

1 Sinchak K, Wagner EJ: Estradiol signaling in the regulation of reproduction and energy balance. Front Neuroendocrinol 2012;33: 342-363.

-2 Sinchak K, Micevych PE: Progesterone blockade of estrogen activation of $\mu$-opioid receptors regulates reproductive behavior. J Neurosci 2001;21:5723-5729.

3 Eckersell CB, Popper P, Micevych PE: Estrogen-induced alteration of mu-opioid receptor immunoreactivity in the medial preoptic nucleus and medial amygdala. J Neurosci 1998; 18:3967-3976.
4 Mills RH, Sohn RK, Micevych PE: Estrogeninduced mu-opioid receptor internalization in the medial preoptic nucleus is mediated via neuropeptide $\mathrm{Y}-\mathrm{Y} 1$ receptor activation in the arcuate nucleus of female rats. J Neurosci 2004;24:947-955.

5 Sanathara NM, Moraes J, Kanjiya S, Sinchak $\mathrm{K}$ : Orphanin FQ in the mediobasal hypothalamus facilitates sexual receptivity through the deactivation of medial preoptic nucleus muopioid receptors. Horm Behav 2011;60:540548. 
-6 Sinchak K, Micevych P: Visualizing activation of opioid circuits by internalization of $\mathrm{G}$ protein-coupled receptors. Mol Neurobiol 2003; 27:197-222.

7 Dewing P, Boulware MI, Sinchak K, Christensen A, Mermelstein PG, Micevych P: Membrane estrogen receptor-alpha interactions with metabotropic glutamate receptor 1a modulate female sexual receptivity in rats. J Neurosci 2007;27:9294-9300.

8 Dewing P, Christensen A, Bondar G, Micevych $P$ : Protein kinase $C$ signaling in the hypothalamic arcuate nucleus regulates sexual receptivity in female rats. Endocrinology 2008; 149:5934-5942.

-9 Micevych P, Dominguez R: Membrane estradiol signaling in the brain. Front Neuroendocrinol 2009;30:315-327.

10 Christensen A, Dewing P, Micevych P: Membrane-initiated estradiol signaling induces spinogenesis required for female sexual receptivity. J Neurosci 2011;31:17583-17589.

-11 Christensen A, Micevych P: Cav1 siRNA reduces membrane estrogen receptor-alpha levels and attenuates sexual receptivity. Endocrinology 2012;153:3872-3877.

12 Quesada A, Micevych P: Estrogen and progesterone modulate [35s]GTPgammaS binding to nociceptin receptors. Neuroendocrinology 2008; $88: 35-42$.

-13 Pelletier G, Li S, Luu-The V, Labrie F: Oestrogenic regulation of pro-opiomelanocortin, neuropeptide $\mathrm{Y}$ and corticotrophin-releasing hormone mRNAs in mouse hypothalamus. J Neuroendocrinol 2007;19:426-431.

14 Hammer RP: Mu-opiate receptor binding in the medial preoptic area is cyclical and sexually dimorphic. Brain Res 1990;515:187-192.

15 Wilcox JN, Roberts JL: Estrogen decreases rat hypothalamic proopiomelanocortin messenger ribonucleic acid levels. Endocrinology 1985;117:2392-2396.

-16 Baskin DG, Norwood BJ, Schwartz MW, Koerker DJ: Estradiol inhibits the increase of hypothalamic neuropeptide Y messenger ribonucleic acid expression induced by weight loss in ovariectomized rats. Endocrinology 1995; 136:5547-5554.

17 Priest CA, Roberts JL: Estrogen and tamoxifen differentially regulate beta-endorphin and cFos expression and neuronal colocalization in the arcuate nucleus of the rat. Neuroendocrinology 2000;72:293-305.

-18 Cheung S, Hammer R: Gonadal steroid hormone regulation of proopiomelanocortin gene expression in the arcuate neurons that innervate the medial preoptic are of the rat. Neuroendocrinology 1995;62:283-292.

19 Cheung S, Salinas J, Hammer R: Gonadal steroid hormone-dependence of $\beta$-endorphinlike immunoreactivity in the medial preoptic area of the rat. Brain Res 1995;675:83-88.

$>20$ Hammer RP Jr, Zhou L, Cheung S: Gonadal steroid hormones and hypothalamic opioid circuitry. Horm Behav 1994;28:431-437.
21 Sinchak K, Romeo HE, Micevych PE: Sitespecific estrogen and progestin regulation of orphanin FQ/nociceptin and nociceptin opioid receptor mRNA expression in the female rat limbic hypothalamic system. J Comp Neurol 2006;496:252-268.

22 Nomenclature guidelines for authors. $\mathrm{Br} \mathrm{J}$ Pharm 2003;138:725-729.

23 Sinchak K, Hendricks DG, Baroudi R, Micevych PE: Orphanin FQ/nociceptin in the ventromedial nucleus facilitates lordosis in female rats. Neuroreport 1997;8:3857-3860.

24 Blaustein JD, Feder HH: Cytoplasmic progestin receptors in female guinea pig brain and their relationship to refractoriness in expression of female sexual behavior. Brain Res 1979;177:489-498.

25 Blaustein JD, Feder HH: Nuclear progestin receptors in guinea pig brain measured by an in vitro exchange assay after hormonal treatments that affect lordosis. Endocrinology 1980;106:1061-1069.

-26 Blaustein JD, Torcotte JC: Estradiol-induced progestin receptor immunoreactivity is found only in estrogen receptor-immunoreactive cells in guinea pig brain. Neuroendocrinology 1989;49:454-461.

27 Sinchak K, Dewing P, Cook M, Micevych P: Release of orphanin FQ/nociceptin in the medial preoptic nucleus and ventromedial nucleus of the hypothalamus facilitates lordosis. Horm Behav 2007;51:406-412.

28 Wagner EJ, Ronnekleiv OK, Grandy DK, Kelly MJ: The peptide orphanin FQ inhibits betaendorphin neurons and neurosecretory cells in the hypothalamic arcuate nucleus by activating an inwardly-rectifying $\mathrm{K}+$ conductance. Neuroendocrinology 1998;67:73-82.

29 Borgquist A, Kachani M, Tavitian N, Sinchak $\mathrm{K}$, Wagner EJ: Estradiol negatively modulates the pleiotropic actions of orphanin $\mathrm{FQ} /$ nociceptin at proopiomelanocortin synapses. Neuroendocrinology 2013;98:60-72.

30 Borgquist A, Mela Rivas V, Kachani M, Sinchak K, Wagner E: Gonadal steroids differentially modulate the actions of orphanin FQ/ nociceptin at a physiologically relevant circuit controlling female sexual receptivity. J Neuroendocrinol 2014;26:329-340.

31 Paxinos G, Watson C: The Rat Brain in Stereotaxic Coordinates, ed 6. San Diego, Academic Press, 2007.

-32 Sinchak K, Dewing P, Ponce L, Gomez L, Christensen A, Berger M, Micevych P: Modulation of the arcuate nucleus-medial preoptic nucleus lordosis regulating circuit: a role for $\mathrm{GABA}_{\mathrm{B}}$ receptors. Horm Behav 2013;64:136-143.

33 Lockwood AH: Molecules in mammalian brain that interact with the colchicine site on tubulin. Proc Natl Acad Sci USA 1979;76: 1184-1188.

34 Chung WC, Pak TR, Weiser MJ, Hinds LR, Andersen ME, Handa RJ: Progestin receptor expression in the developing rat brain depends upon activation of estrogen receptor alpha and not estrogen receptor beta. Brain Res 2006;1082:50-60.
35 Wagner CK, Pfau JL, De Vries GJ, Merchenthaler IJ: Sex differences in progesterone receptor immunoreactivity in neonatal mouse brain depend on estrogen receptor alpha expression. J Neurobiol 2001;47:176-182.

36 Abercrombie M: Estimation of nuclear population from microtome sections. Anat Rec 1946;94:239-247.

37 Paxinos G, Watson C: The Rat Brain in Stereotaxic Coordinates, ed 2. Orlando, Academic Press, 1986.

38 Greco B, Allegretto EA, Tetel MJ, Blaustein JD: Coexpression of ER beta with ER alpha and progestin receptor proteins in the female rat forebrain: effects of estradiol treatment. Endocrinology 2001;142:5172-5181.

-39 Parsons B, MacLusky NJ, Kreiger MS, McEwen BS, Pfaff DW: The effects of long-term estrogen exposure on the induction of sexual behavior and measurements of brain estrogen and progestin receptors in the female rat. Horm Behav 1979;13:301-313.

40 Jegou S, Boutelet I, Vaudry H: Melanocortin-3 receptor mRNA expression in pro-opiomelanocortin neurones of the rat arcuate nucleus. J Neuroendocrinol 2000;12:501-505.

-41 Mahavongtrakul M, Kanjiya MP, Maciel M, Kanjiya S, Sinchak K: Estradiol dose-dependent regulation of membrane estrogen receptor-alpha, metabotropic glutamate receptor$1 \mathrm{a}$, and their complexes in the arcuate nucleus of the hypothalamus in female rats. Endocrinology 2013;154:3251-3260.

-42 Neal CR, Mansour A, Reinscheid R, Nothacker HP, Civelli O, Akil H, Watson SJ: Opioid receptor-like (ORL1) receptor distribution in the rat central nervous system: Comparison of ORL1 receptor mRNA expression with I-125-[(14)Tyr]-orphanin FQ binding. J Comp Neurol 1999;412:563-605.

43 Nestor CC, Coolen LM, Nesselrod GL, Valent M, Connors JM, Hileman SM, Cheng G, Lehman MN, Goodman RL: Evidence that orphanin FQ mediates progesterone negative feedback in the ewe. Endocrinology 2013;154: 4249-4258.

44 An XF, Yu JY, Feng Y, Chen BY, Zhang SL: Role of hypothalamus nociceptin/orphanin FQ in pre-ovulatory luteinizing hormone surge of estrogen and progesterone-primed, ovariectomized rats. Acta Pharmacol Sin 2007;28:1189-1197.

45 Mana A, Garcia BL, Fuentes KN, Sinchak K Differential activation/deactivation of lordosis circuit is dependent on estradiol dosage (abstract). Washington, Society for Neuroscience, 2009.

46 Micevych P, Sinchak K, Mills RH, Tao L, LaPolt P, Lu JK: The luteinizing hormone surge is preceded by an estrogen-induced increase of hypothalamic progesterone in ovariectomized and adrenalectomized rats. Neuroendocrinology 2003;78:29-35.

-47 Treiser SL, Wardlaw SL: Estradiol regulation of proopiomelanocortin gene expression and peptide content in the hypothalamus. Neuroendocrinology 1992;55:167-173. 
-48 Petersen SL, Keller ML, Carder SA, McCrone $S$ : Differential effects of estrogen and progesterone on levels of POMC messenger RNA levels in the arcuate nucleus - relationship to the timing of LH surge release. J Neuroendocrinol 1993;5:643-648.

-49 Bloch GJ, Babcock AM, Gorski RA, Micevych PE: Cholecystokinin stimulates and inhibits lordosis behavior in female rats. Physiol Behav 1987;39:217-224.

-50 Bohler HC Jr, Tracer H, Merriam GR, Petersen SL: Changes in proopiomelanocortin messenger ribonucleic acid levels in the rostral periarcuate region of the female rat during the estrous cycle. Endocrinology 1991; 128:1265-1269.

51 Micevych PE, Kelly MJ: Membrane estrogen receptor regulation of hypothalamic function. Neuroendocrinology 2012;96:103-110.

52 Blakley GG, Pohorecky LA, Benjamin D: Behavioral and endocrine changes following antisense oligonucleotide-induced reduction in the rat NOP receptor. Psychopharmacology (Berl) 2004;171:421-428.

53 Devine DP, Watson SJ, Akil H: Nociceptin/ orphanin FQ regulates neuroendocrine function of the limbic-hypothalamic-pituitaryadrenal axis. Neuroscience 2001;102:541553.

54 Wardlaw SL: Hypothalamic proopiomelanocortin processing and the regulation of energy balance. Eur J Pharmacol 2011;660:213-219.

55 Farhang B, Pietruszewski L, Lutfy K, Wagner EJ: The role of the NOP receptor in regulating food intake, meal pattern, and the excitability of proopiomelanocortin neurons. Neuropharmacology 2010;59:190-200.

-56 Butera PC, Czaja JA: Intracranial estradiol in ovariectomized guinea pigs: effects on ingestive behaviors and body weight. Brain Res 1984;322:41-48.

57 Czaja JA, Goldfoot DA, Karavolas HJ: Comparative facilitation and inhibition of lordosis in the guinea pig with progesterone, 5-alphapregnane-3,2-dione, or 3-alpha-hydroxy5-alpha-pregnan-20-one. Horm Behav 1974; 5:261-274.

-58 Dubuc PU: Effects of estrogen on food intake, body weight, and temperature of male and female obese mice. Proc Soc Exp Biol Med 1985; 180:468-473.

59 Palmer K, Gray JM: Central versus peripheral effects of estrogen on food intake and lipoprotein lipase activity in ovariectomized rats. Physiol Behav 1986;37:187-189.

-60 Santollo J, Wiley MD, Eckel LA: Acute activation of ER alpha decreases food intake, meal size, and body weight in ovariectomized rats. Am J Physiol Regul Integr Comp Physiol 2007;293:R2194-R2201.
61 Pomonis JD, Billington CJ, Levine AS: Orphanin $F Q$, agonist of orphan opioid receptor ORL1, stimulates feeding in rats. Neuroreport 1996;8:369-371.

62 Stratford TR, Holahan MR, Kelley AE: Injections of nociceptin into nucleus accumbens shell or ventromedial hypothalamic nucleus increase food intake. Neuroreport 1997;8: 423-426.

63 Polidori C, Calo G, Ciccocioppo R, Guerrini R, Regoli D, Massi M: Pharmacological characterization of the nociceptin receptor mediating hyperphagia: identification of a selective antagonist. Psychopharmacology (Berl) 2000; 148:430-437.

64 Economidou D, Policani F, Angellotti T, Massi M, Terada T, Ciccocioppo R: Effect of novel NOP receptor ligands on food intake in rats. Peptides 2006;27:775-783.

65 Tajalli S, Jonaidi H, Abbasnejad M, Denbow DM: Interaction between nociceptin/orphanin FQ (N/OFQ) and GABA in response to feeding. Physiol Behav 2006;89:410-413.

-66 Roepke TA: Oestrogen modulates hypothalamic control of energy homeostasis through multiple mechanisms. J Neuroendocrinol 2009;21:141-150.

67 Bomberg EM, Grace MK, Levine AS, Olszewski PK: Functional interaction between nociceptin/orphanin FQ and alpha-melanocyte-stimulating hormone in the regulation of feeding. Peptides 2006;27:1827-1834.

68 Taylor JA, Goubillon ML, Broad KD, Robinson JE: Steroid control of gonadotropin-releasing hormone secretion: associated changes in pro-opiomelanocortin and preproenkephalin messenger RNA expression in the ovine hypothalamus. Biol Reprod 2007;76: 524-531.

69 Kalra SP: Mandatory neuropeptide-steroid signaling for the preovulatory luteinizing hormone-releasing hormone discharge. Endocrine Rev 1993; 14:507-538.

70 Richter TA, Robinson JE, Evans NP: Progesterone treatment that either blocks or augments the estradiol-induced gonadotropinreleasing hormone surge is associated with different patterns of hypothalamic neural activation. Neuroendocrinology 2001;73:378386.

71 Goodman RL, Parfitt DB, Evans NP, Dahl GE, Karsch FJ: Endogenous opioid peptides control the amplitude and shape of gonadotropin-releasing hormone pulses in the ewe. Endocrinology 1995;136:2412-2420.

72 Goodman RL, Gibson M, Skinner DC, Lehman MN: Neuroendocrine control of pulsatile GnRH secretion during the ovarian cycle: evidence from the ewe. Reproduction 2002; 59:41-56.
73 Foradori CD, Amstalden M, Coolen LM, Singh SR, McManus CJ, Handa RJ, Goodman RL, Lehman MN: Orphanin FQ: Evidence for a role in the control of the reproductive neuroendocrine system. Endocrinology 2007; 148:4993-5001.

74 Dhandapani KM, Brann DW: Orphanin FQ inhibits $\mathrm{GnRH}$ secretion from rat hypothalamic fragments but not GTI-7 neurons. Neuroreport 2002;13:1247-1249.

75 Liu X, Herbison AE: Small-conductance calcium-activated potassium channels control excitability and firing dynamics in gonadotropin-releasing hormone $(\mathrm{GnRH})$ neurons. Endocrinology 2008;149:3598-3604.

76 Clarkson J, Herbison AE: Postnatal development of kisspeptin neurons in mouse hypothalamus; sexual dimorphism and projections to gonadotropin-releasing hormone neurons. Endocrinology 2006; 147:5817-5825.

-77 Smith JT, Popa SM, Clifton DK, Hoffman GE, Steiner RA: Kiss1 neurons in the forebrain as central processors for generating the preovulatory luteinizing hormone surge. J Neurosci 2006;26:6687-6694.

78 Roa J, Navarro VM, Tena-Sempere M: Kisspeptins in reproductive biology: Consensus knowledge and recent developments. Biol Reprod 2011;85:650-660

79 An XF, Chen HP, Ma SL, Feng Y, Hao JW Chen BY: Involvement of nociceptin/orphanin FQ in release of hypothalamic GnRH mediated by ORL1 receptor in ovariectomized rats. Acta Pharmacol Sin 2005;26: 1039-1044.

80 Feder HH, Brown-Grant K, Corker CS: Preovulatory progesterone, the adrenal cortex and the 'critical period' for luteinizing hormone release in rats. J Endocrinol 1971;50: 29-39.

81 Kalra SP, Kalra PS: Temporal interrelationships among circulating levels of estradiol, progesterone and LH during the rat estrous cycle: effects of exogenous progesterone. Endocrinology 1974;95:1711-1718.

82 Smith MS, Freeman ME, Neill JD: The control of progesterone secretion during the estrous cycle and early pseudopregnancy in the rat: prolactin, gonadotropin and steroid levels associated with rescue of the corpus luteum of pseudopregnancy. Endocrinology 1975;96: 219-226.

83 Goodman RL, Inskeep EK: Control of the ovarian cycle in the sheep; in Neill JD (ed): Knobil's and Neill's Physiology of Reproduction. Amsterdam, Elsevier, 2006, pp 23892447.

84 Swanson LW: Brain Maps: Structure of the Rat Brain, ed 3. San Diego, Elsevier, 2004. 